\title{
To drive or be driven: the path of a mouse model of recurrent pregnancy loss
}

\author{
Elizabeth A Bonney and Stephen A Brown \\ Division of Reproductive Sciences, Department of Obstetrics, Gynecology and Reproductive Sciences, University of \\ Vermont College of Medicine, Given Building, 89 Beaumont Avenue, Burlington, Vermont 05404, USA \\ Correspondence should be addressed to E A Bonney; Email: ebonney@uvm.edu
}

\begin{abstract}
This review is an example of the use of an animal model to try to understand the immune biology of pregnancy. A well-known model of recurrent spontaneous pregnancy loss is put in clinical, historical, and theoretical context, with emphasis on T cell biology.

Reproduction (2014) 147 R153-R167
\end{abstract}

\section{Introduction}

The 'problem of viviparity' (Medawar 1954) remains among the most fundamental questions in biology. From an immunological standpoint, this problem stems from the conundrum presented by the fetus as a 'semiallograft' and the mother's need to both protect and tolerate the fetus. The implications of the relationship(s) between the mother, fetus, and immune system reach clinical significance with regard to emerging infectious disease, vaccinations, autoimmunity, specific disease of pregnancy, fetal development, and neonatal health. It has been our hypothesis that understanding of critical clinical and basic biological problems can result from the iterative use of good clinical/epidemiological data and well-understood animal models (Bonney 2013). Such an approach should lead to significant progress not only in our understanding of pregnancy but also in logical and successful clinical intervention.

Depending on one's viewpoint, it seems that studies using animal models of pregnancy-related disease, as compared with study of other disease models, have failed to deliver. Why? As outsiders, we would posit that due to unrecognized subtle and not so subtle differences in human and animal physiology the models themselves take some of the blame (Bonney 2013) but not all of it. In addition, we propose that the theoretical framework which elicited the use of and interpretation of the data generated by these models, and, further, the experimental direction lead by this interpretation may have impeded the finding of solutions. To support this assertion, what follows is a focused discussion of one animal model wherein female mice of the $\mathrm{CBA} / \mathrm{J}$ strain mated with male mice of the DBA/2 strain experience a high rate of reproductive failure. We think the theoretical context that drives the use of this model is founded on classical immune theory of how the maternal immune system decides between activation and tolerance, namely the discrimination between self and nonself. We will discuss how this model appears to have driven thinking about the $T$ cell biology of pregnancy, and how thinking about this model might be redirected in the context of an alternative to self/nonself determination theory (Matzinger 1994, Bonney 2007) to generate experiments leading to better understanding. Figure 1 illustrates the path of the model and our discussion.

\section{A driver: the clinical problem of recurrent spontaneous pregnancy loss}

It has long been recognized that there are couples who suffer from recurrent pregnancy loss (see Branch et al. (2010) for a recent review). The most concerning are those who never had a successful pregnancy and who at a similar time in each of several pregnancies suffered this loss. While some of this phenomenon was attributed to such factors as chromosomal defects (Kim et al. 1975), progesterone insufficiency (Shearman \& Garrett 1963), uterine anomalies (Branch et al. 2010), or psychosocial factors (Weil \& Tupper 1960), many of these factors were hotly debated and it soon became clear that that there was a subset of couples for whom no cause could be found (Christiansen et al. 2008). Over many years, several lines of evidence (briefly summarized here) have suggested the involvement of the immune system in this disease. Earlier (e.g. McIntyre \& Faulk (1983) and Mclntyre et al. (1989)) and more recent studies have suggested a role for HLA and minor antigens (e.g. Nielsen et al. (2009) and Christiansen et al. (2012)) in 

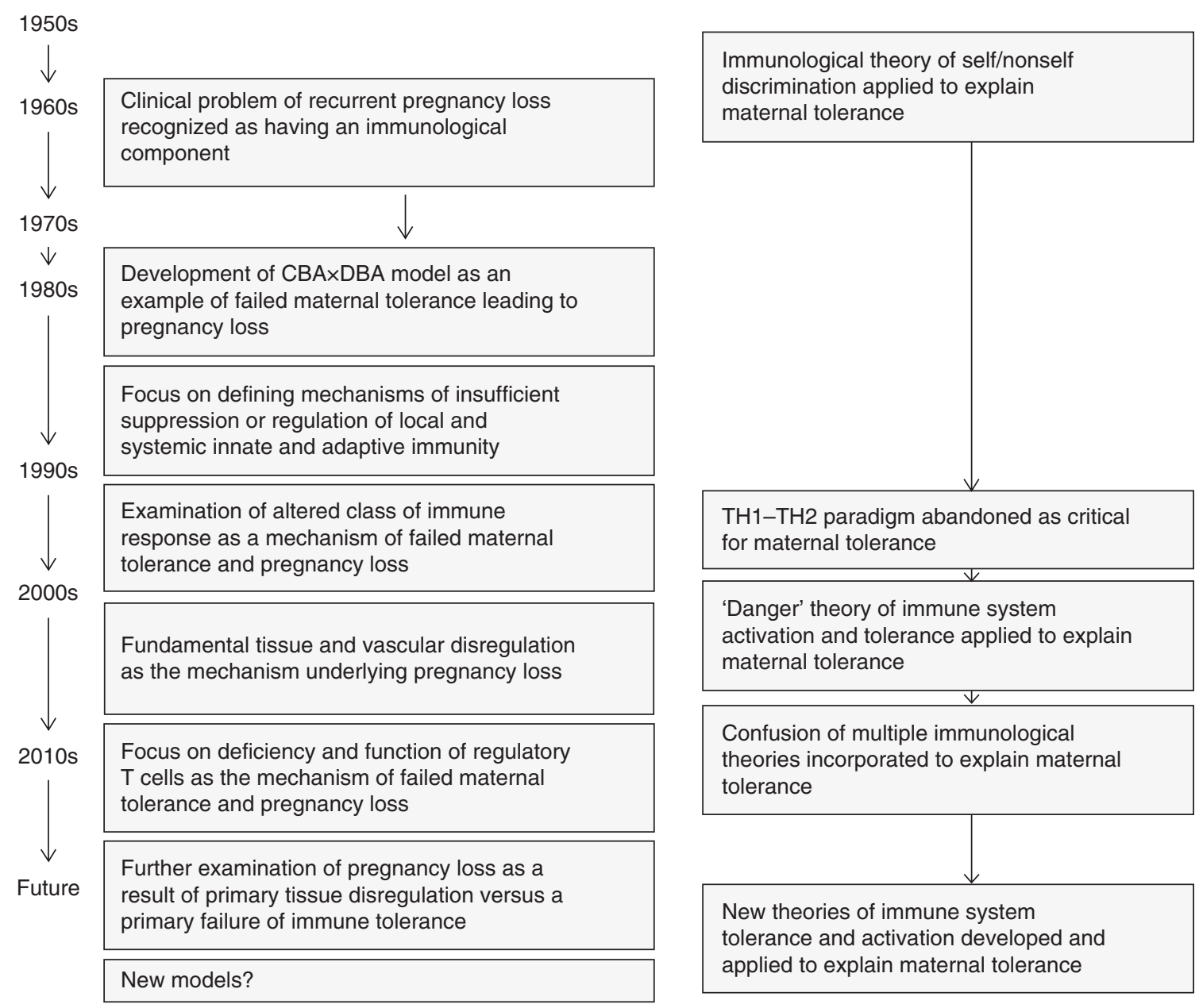

Figure 1 Immune theory and the path of the CBA $\times$ DBA model.

recurrent pregnancy loss. Moreover, the association between the generation of auto-antibodies, autoimmune disease (Firkin et al. 1980), disorders of complement regulation (Laitinen et al. 1991), and recurrent pregnancy loss then and now (Oku et al. 2009, Mohlin et al. 2013) supports the idea that the immune system plays a role in this disease. In addition, there exists evidence of the important role played by natural killer cells, both in normal pregnancy (Bulmer et al. 1991, Koopman et al. 2003) and in recurrent pregnancy loss, with the later thought to stem from lack of trophic supportive (e.g. growth and development) activity and/or overactive killer activity (Nakashima et al. 2012), although this remains controversial (Tang etal. 2011) and awaits further study (Tang et al. 2013). Earlier studies of distinct immune-reactive antigens expressed on the human placenta (e.g. Faulk et al. (1978)) suggested the possibility of alternative flavors of immune responses some protective and some harmful to the fetal-placental unit (McIntyre \& Faulk 1979, Ecker et al. 1993). Finally, there is evidence supporting an association between altered decidual $\mathrm{T}$ cell populations and recurrent pregnancy loss (Sasaki et al. 2004, Nakashima et al. 2012, Inada et al. 2013).
Immune theory, bolstered by years of basic experimental data, suggested that the immune system's primary and activating focus was to respond to that which was nonself. Pregnancy was considered an example of this theory (Medawar 1954), and successful pregnancy was considered critically dependent on suppression of maternal immunity. However, it had been observed that human (Faulk \& McIntyre 1983, McIntyre et al. 1983) and animal females could make complex immune responses to fetal/placental antigens during normal pregnancy. An early, prominent report suggested that women with recurrent abortion who shared several HLA antigens with their partners could be 'immunized' by transfusion with allogeneic leukocytes (Taylor \& Faulk 1981) to enhance fetal-protective immunity and therefore helped to have successful pregnancies. Although subsequent randomized trials and meta-analyses have cast some doubt on its use in most couples (Ober et al. 1999, Porter et al. 2006), the possibility of an immunebased therapy for recurrent abortion at that time supported the development of animal models to address the issue. 


\section{The origins of the ' $C B A \times D B A$ ' model}

\section{History of the mouse strains}

CBA/J has been maintained at Jackson Laboratories (Bar Habor, ME, USA) since 1948 (Table 1). It was originally created in as an inbred strain in 1920 by Strong, by crossing a Bagg albino female with a DBA/2 male (see http://jaxmice.jax.org). CBA/J mice were selected for having a low incidence of mammary tumors. Based on this history, modern $\mathrm{CBA} / \mathrm{J}$ and DBA/2 are expected to be genetically identical at half of all loci. Like all inbred strains, CBA/J has some specific features. In particular, $\mathrm{CBA} / \mathrm{J}$ mice are homozygous for Pde6b ${ }^{\text {rd1 }}$ (phosphodiesterase 6B, cGMP, rod receptor, and beta polypeptide), which is a mutation causing early retinal degeneration and blindness by the age of weaning. Thus, all CBA/J adult mice are blind. In addition, CBA/J mice are known to have a high incidence of tubulointerstitial renal lesions.

DBA mice are the oldest of all inbred strains and were originally developed by Little. DBA/1 and DBA/2 were established as sub-strains in 1929-1930. DBA/2 mice are homozygous for a mutation that results in progressive hearing loss. In addition, DBA/2 mice develop progressive glaucoma-like eye abnormalities, the inheritance of which involves at least two genes.

\section{$T$ cell antigens}

These two strains were among those extensively used to gain understanding of major, minor, and 'super' antigens. CBA/J is (histocompatibility) $\mathrm{H}-2$ haplotype $k$. The CBA/J H2-T23 (Qa1) and H2-T18 types are both b (Fischer Lindahl 1997). An important minor antigen presented as a peptide in a histocompatibility molecule and capable of inducing tissue graft rejection by females is the male antigen, H-Y (Scott et al. 1997, Simpson et al. 1997). $\mathrm{CBA} / \mathrm{J}$ is a 'non responder' to the male antigen $\mathrm{H}-\mathrm{Y}$ (Gordon et al. 1975, von Boehmer et al. 1978), although $\mathrm{CBA} / \mathrm{J} \times \mathrm{C} 57 \mathrm{BL} / 6 \mathrm{~F} 1$ female mice do respond to this antigen. Both $\mathrm{CBA} / \mathrm{J}$ and $\mathrm{DBA} / 2$ mice express the mouse mammary tumor virus locus 7 allele originally called Mls- ${ }^{a}$. Strains carrying this allele delete $T$ cells expressing specific $\mathrm{V}$ beta chains (e.g. $\mathrm{V}$ beta 8.1) from their peripheral T cell pool (Kappler et al. 1988). $\mathrm{DBA} / 2$ is $\mathrm{H}-2$ haplotype $d$, its H2-T23 (Qa1) type is b (Fischer Lindahl 1997), and its H2-T18 type is C. DBA/2 mice have the unique characteristic that they do not express the NK cell surface receptor CD94/NKG2A, due to a deletion within the Klrd2 gene (Vance et al. 2002). Balb/c mice are $\mathrm{H}-2 \mathrm{~d}$, their $\mathrm{H} 2-\mathrm{T} 23$ and $\mathrm{H} 2-\mathrm{T} 18$ types are the same as DBA/2, and their Mtv7 type is b. $\mathrm{Balb} / \mathrm{C}$ mice do not respond to the male antigen $\mathrm{H}-\mathrm{Y}$ (von Boehmer et al. 1978).

\section{The pregnancy-loss phenotype}

CBA/J mice have been housed and bred in several facilities around the world. The primary model comprises a comparison between $\mathrm{CBA} / \mathrm{J}$ females mated to DBA/2 males and CBA/J females mated to males of other strains, including $\mathrm{C} 3 \mathrm{H}, \mathrm{C} 57 \mathrm{BL} / 6$, and the most common, $\mathrm{Balb} / \mathrm{c}$. Early studies suggested a high rate of nonpregnancy in DBA/2-mated CBA/J females (Clark et al. 1980). However, mothers of related CBA/J strains, CBA/ $\mathrm{Ca}$ and $\mathrm{CBA} / \mathrm{N}$, do not exhibit this phenomenon (Bobe \& Kiger 1989). Investigators have noted that in DBA/ 2-mated CBA/J females, beginning around day 7 of

Table 1 Genetic and immunogenetic features of the CBA $\times$ DBA model.

\begin{tabular}{|c|c|c|c|c|c|c|c|}
\hline Strain & Origin & MHC & $\begin{array}{c}\text { H2-T23 } \\
\text { (Qa1) }\end{array}$ & H2-T18 & MMTV-7 & $\begin{array}{l}\text { Known features/ } \\
\text { mutations }\end{array}$ & $\begin{array}{l}\text { Response to the male } \\
\text { antigen H-Y }\end{array}$ \\
\hline CBA/J & $\begin{array}{l}\text { Cross between Bagg } \\
\text { female and DBA } \\
\text { male in 1920; } \\
\text { selected for low } \\
\text { incidence of } \\
\text { mammary tumors }\end{array}$ & H-2 haplotype $k$ & $\mathrm{~b}$ & $\mathrm{~b}$ & $\mathrm{a}$ & $\begin{array}{l}\text { Homozygous for the } \\
\text { retinal degeneration } \\
\text { allele Pde } 6 b^{r d 1} \text {; causes } \\
\text { blindness } \\
\text { High frequency of renal } \\
\text { tubulointerstitial lesions }\end{array}$ & Nonresponder \\
\hline $\mathrm{DBA} / 2$ & $\begin{array}{l}\text { Oldest of all inbred } \\
\text { strains; produced by } \\
\text { Little }\end{array}$ & $\mathrm{H}-2$ haplotype $d$ & b & $\mathrm{C}$ & $\mathrm{a}$ & $\begin{array}{l}\text { Widely used strain; traits } \\
\text { often contrasted with } \\
\text { C57BL/6J } \\
\text { Hearing loss } \\
\text { CD94 deficient (DBA/2) } \\
\text { Low incidence of } \\
\text { atherosclerosis } \\
\text { Eye abnormality used as } \\
\text { model for glaucoma }\end{array}$ & Nonresponder \\
\hline Balb/c & & H-2 haplotype $d$ & $b$ & $\mathrm{C}$ & $b$ & $\begin{array}{l}\text { Well known for suscep- } \\
\text { tibility to autoimmune } \\
\text { encephalomyelitis (EAE) } \\
\text { Widely used for the } \\
\text { production of } \\
\text { monoclonal antibodies }\end{array}$ & Nonresponder \\
\hline
\end{tabular}


gestation, there is a loss of cellular contact between decidual cells and cells of the ectoplacental cone (Gendron \& Baines 1989). This is accompanied by an infiltration of natural killer and nonnatural killer leukocytes, including T and B cells (Gendron \& Baines 1988, 1989). Later studies also suggest that resorbing tissues have an increased infiltration of mast cells (Zenclussen et al. 2003). The pathology of these pregnancies progresses by day 8 to comprising increased tissue spaces and abnormal syncytium formation by day 9 (Gendron \& Baines 1989). Finally, by days 10-12, there is evidence of embryonic loss and pronounced infiltration of polymorphonuclear leukocytes, CD8positive and -negative T cells, and B cells. By day 12, there is a clear difference between 'resorbing' fetal placental units and normal units, whereby the resorbing units are dark, small, and necrotic, with indeterminant fetal and placental elements, while normal fetal placental units are pink and show overt evidence of a developed placenta separate from a fetus within an amniotic sac. From this discussion, it should be obvious that not every fetal-placental unit undergoes resorption. In addition, from time to time, fetal placental units resorb in all strains. The importance of specific factors that differentiate resorbing from non-resorbing fetal placental units in either 'normal' or 'abnormal' strain combinations appears to have been afforded less relevance in the study of this model.

Although it has been reported that the number of early implantation sites in this breeding is relatively normal (Chavez et al. 1987), ultimately, litter size in CBA/J $\times$ $\mathrm{DBA} / 2$ matings is variable, from two to eight pups per litter (Heine et al. 1989). Data on litter size are not as prevalent as data on what is called "resorption". Pregnancy loss in the $\mathrm{CBA} / \mathrm{J} \times \mathrm{DBA} / 2$ model is usually reported as the number (or percent) of resorptions/total number of implantations $(R / T)$, pooling data from individual mice (Clark et al. 2008a) and this is deemed preferable to reporting median and range of resorbed units or to comparing data from individual mice. The percentage of resorbing fetal-placental units in this mating are highly variable, with some values as low as $10 \%$ and others upwards of $80 \%$ depending on several factors - in particular, the microbial barrier status of husbandry (Hamilton \& Hamilton 1987, Clark et al. 2003). A large range in resorption rate can be seen within the same set of experiments (Clark et al. 1994). There also appears to be some variability with regard to second pregnancies in this mating, with most reports suggesting that second pregnancies decrease the resorption rate (Chavez et al. 1987, Clark et al. 1994, Ahmed et al. 2010). However, this has not been observed by all investigators (Baines et al. 1996). This later discrepancy may be related to the time-lapse between the first and second pregnancies. As in human populations, this mating combination experiences increased pregnancy loss with increasing maternal age (Chavez et al. 1987, Ho et al. 1994).

\section{Evolving views of immune suppression and the ' $\mathrm{CBA} / \mathrm{J} \times \mathrm{DBA}^{\prime}$ ' model}

\section{Inherent pregnancy-related suppression?}

Clonal selection theory and the related self/nonself discrimination model of immune system activation (Burnet 1962) led immunologists to suggest model(s) wherein the maternal immune system was suppressed during normal pregnancy (Medawar 1954). Though some early studies (e.g. Clark \& McDermott (1978)) documented the expansion rather than contraction of maternal lymphoid tissue during allogeneic pregnancy, this theoretical context, and studies in humans (Finn et al. 1972), and varied animal species (e.g. armadillos, Anderson \& Benirschke (1964)) drove the search for immune-suppressive factors. It was thought that the expression of such factors in lymphoid and other tissues (e.g. placenta) would affect both systemic and local immunity of pregnant mice and support fetal tolerance. The $\mathrm{CBA} / \mathrm{J} \times \mathrm{DBA} / 2$ model first arose in the context of delineating these putative suppressive factors (Clark et al. 1980) as the model was held up as an example of adverse pregnancy outcome (resorption) in the face of deficiency of such suppression (Clark et al. 1980). Continued study of the model was also a venue for examining the production of soluble suppressive factors produced in the placenta or decidua. For example, it was observed that a factor in normal fetal-placental units suppressed systemic NK cell activity, but that this factor was not in CBA/J $\times D B A / 2$ (Gendron et al. 1990). However, these factors were not tested on purified populations of local (decidual) NK cells. Another issue that deserved analysis was, given this suppressor factor, the mechanisms which led to the resorption of some fetal-placental units and not others.

Early investigations suggested that within the uterus there is an early infiltration of a CD8 T cell population with suppressive activity which later gives way to a non-T cell suppressor population (Clark et al. 1989). However, it was not clear the extent to which the infiltration of these cells is deficient in normal vs resorption-prone matings. Through examination of this model, another population of cells thought to provide site-specific suppressor activity was described as consistent with $\gamma-\delta$ T cells (Clark et al. 1997) and although depletion on days 8-9 of gestation increased the resorption rate (Arck et al. 1999), peri-implantation depletion of this T cell subset had no effect. Although apparently not available in the $\mathrm{CBA} / \mathrm{J}$ strain background, generally available strains of mice deficient in this particular cell type are not known to have an overt pregnancy failure (see http://jaxmice.jax.org). 


\section{Is the model evidence of antigen-specific, $T$ cell-mediated resorption?}

$\mathrm{CBA} / \mathrm{J} \times \mathrm{DBA} / 2$ pregnancies are 'semi-allogeneic', in that $\mathrm{CBA} / \mathrm{J}$ are $\mathrm{H}-2 \mathrm{k}$ and $\mathrm{DBA} / 2$ mice are $\mathrm{H}-2 \mathrm{~d}$. A potential myriad of minor and other antigens might be relevant in the immune response of the $\mathrm{CBA} / \mathrm{J}$ immune system against DBA/2 cells, yet the specific antigenic focus of the resorption-generating immune response is not known. Nor is it clear which cell is the primary effector. Histologic and other findings suggest that NK cells (de Fougerolles \& Baines 1987, Gendron \& Baines 1988), macrophages (Redecha et al. 2009), and neutrophils (Gendron \& Baines 1989, Girardi 2011) play an important role in the pregnancy loss observed in this model. Over time, however, the drive to understand pregnancy loss in the context of self/nonself theory leads to an examination of T cell biology, and in particular defects in $\mathrm{T}$ cell tolerance as a major mechanism of pathology. Several studies suggested that pregnancy loss in the $\mathrm{CBA} / \mathrm{J} \times \mathrm{DBA} / 2$ model was related to altered $\mathrm{T}$ cell function. For example, low but not high doses of cyclosporine A (Du et al. 2007, Zhou et al. 2008), blockade of T cell co-stimulation (Jin et al. 2004, Zhu et al. 2005), and overexpression of the T cell regulatory molecule CTLA4 (Li et al. 2009) decreased resorptions.

These studies led to examinations in other mating combinations and suggested a role for $\mathrm{T}$ cell-mediated resorption (Riella et al. 2013). One of these important studies in another mating combination investigated the role of the molecule indoleamine 2,3-dioxygenase (IDO), which catabolizes tryptophan and thus limits $\mathrm{T}$ cell proliferation (Munn et al. 1998, Mellor \& Munn 2001). Although the presence of $\mathrm{T}$ cells and an allogeneic mating was required for pregnancy loss in response to inhibition of IDO, no $\mathrm{T}$ cell antigen specificity was demonstrated (e.g. specific attack of antigen-expressing fetal-placental units vs nonantigen expressing units in the same uterus), suggesting that the $T$ cell response may have been a 'bystander' effect but not the primary mover of the immune response. It should also be noted that deficiency in IDO does not negate pregnancy in other strain combinations (Riella et al. 2013).

Although there is no direct evidence that inhibition of this molecule increases resorption in the $\mathrm{CBA} / \mathrm{J} \times$ $\mathrm{DBA} / 2$ model, the idea that altered IDO expression could be the basis for pregnancy loss in the $\mathrm{CBA} / \mathrm{J} \times$ $\mathrm{DBA} / 2$ model led to experiments showing that enhanced exposure to molecules such as CTLA4 correlates with decreased resorption and increased IDO expression (Li et al. 2009). Here again, however, while these models presume that it is an anti-allogeneic response which leads to resorption, the exact antigen has not been delineated and the specific response has not been demonstrated.

\section{Generation of 'protective immunity' against pregnancy loss}

Another critical element suggesting the role of immune modulation in the $\mathrm{CBA} / \mathrm{J} \times \mathrm{DBA} / 2$ model was developed either concurrent to or in response to the finding that a history of recurrent miscarriage could be ameliorated by transfusion with allogeneic leukocytes (Taylor \& Faulk 1981). Investigators discovered that while administration of $\mathrm{DBA} / 2$ or $\mathrm{CBA} / \mathrm{J}$ spleen cells about 1 week before mating did not decrease the resorption rate, administration of 'third party' Balb/c spleen cells did (Chaouat et al. 1983, Bobe et al. 1986), as long as it occurred within 8 weeks before mating with a DBA/2 male (Baines et al. 1996). Pre-immunization with spleen cells from DBA/2 by Balb/c recombinant strains led to differing results, with some strains decreasing and others increasing the resorbtion rate (Kiger et al. 1985). Early studies suggested that exposure to castrated Balb/c males or even dirty Balb/c male bedding was protective for DBA/2-mated CBA/J females (see Table 2 for representative manipulations of the model and associated references). These studies were precursors to others which provided the observation that exposure to seminal plasma fluids and likely seminal plasmid-related antigenic peptides presented in the context of MHC mediate decreased resorption (Clark et al. 2013). Prior mating to a Balb/c male was also protective, as long as subsequent pregnancy with a DBA/2 male occurred within 6 weeks (Baines et al. 1996).

It appears that mostly male cells were given, although this is not always easily discernible, and in some cases it was observed that administration of female spleen cells did not decrease resorption (Kiger et al. 1985). Moreover, the number of spleen cells given varied, with some giving up to 50 million male spleen cells (Chaouat et al. 1995). A rather unique immunization protocol using C57BL/6 (not Balb/c) male spleen and thymus cells, and multiple immunizations both before pregnancy and up to day 5 of gestation, produced decreased resorptions in $\mathrm{DBA} / 2$-mated $\mathrm{CBA} / \mathrm{J}$ females. However, continued exposure into a second pregnancy increased the resorption rate compared to that seen in unmanipulated $\mathrm{CBA} / \mathrm{J} \times \mathrm{DBA} / 2$ pregnancies (Chavez et al. 1987). This again suggesting fluidity in the protective effect.

While attention was focused on finding the mechanisms leading to enhanced suppression of anti-DBA/2 immunity in CBA/J mothers, the results of pre-pregnancy immunization protocols led to differing findings in the peripheral tissues vs decidua. For example, very early sets of observations suggested that although pre-pregnancy immunization apparently decreased the rate of resorbtion, it did not correlate with suppression of maternal spleen $\mathrm{T}$ cell proliferation, or generation of anti-DBA/2 cytotoxic $\mathrm{T}$ cell activity in vitro in some cases (Bobe et al. 1986), whereas in others it apparently did (Chaouat et al. 1985). Moreover, while pre-pregnancy immunization of $\mathrm{CBA} / \mathrm{J}$ females 
Table 2 Representative manipulations of CBA $\times$ DBA matings (arranged roughly according to mechanism).

\begin{tabular}{|c|c|c|c|}
\hline $\begin{array}{l}\text { Baseline resorption } \\
\text { rate* }(\%)\end{array}$ & Manipulation (injection unless noted) & $\begin{array}{c}\text { Resulting } \\
\text { resorption } \\
\text { rate* }(\%)\end{array}$ & References \\
\hline \multicolumn{4}{|c|}{ Decreased resorption rate } \\
\hline 31 & Second pregnancy & 1 & Chavez et al. (1987) \\
\hline $30-35$ & Second pregnancy & 15 & Gendron et al. (1992) \\
\hline 23 & Add normal Balb/c male to cage on day 6 of 1st pregnancy & 4 & Baines et al. (1994) \\
\hline 23 & Add castrated Balb/c male to cage on day 6 of 1 st pregnancy & 9 & Baines et al. (1994) \\
\hline 23 & Add Balb/c male bedding to cage on day 6 of 1 st pregnancy & 9 & Baines et al. (1994) \\
\hline 30 & Specific pathogen-free room & 8 & $\begin{array}{l}\text { Hamilton \& Hamilton } \\
\quad(1987)\end{array}$ \\
\hline $20-35$ & Balb/c male spleen cells before mating $\#$ & $5-15$ & Kiger et al. (1985) \\
\hline 35 & Balb/c male spleen cells before mating & 20 & Clark et al. (2008b) \\
\hline $20-35$ & Balb/c male spleen cells before mating & 10 & Clark et al. (2013) \\
\hline $20-35$ & Balb/c spleen cells pre-incubated with Balb/c seminal plasma before mating & 3 & Clark et al. (2013) \\
\hline $20-35$ & DBA spleen cells pre-incubated with Balb/c seminal plasma before mating & 10 & Clark et al. (2013) \\
\hline 30 & $\begin{array}{l}\text { Spleen cells from Balb/c } \times \text { DBA recombinant inbred strains } \mathrm{K}, \mathrm{N}, \mathrm{C} \\
\text { before mating }\end{array}$ & $5-17$ & Kiger et al. (1985) \\
\hline 24 & $\begin{array}{l}\text { CBA bone marrow-derived dendritic cells pulsed with lysate of } \\
\text { DBA male spleen cells }\end{array}$ & 5 & Blois et al. (2004) \\
\hline 24 & Anti-CD11b antibody i.v. on day 6 & 12 & Duclos et al. (1994) \\
\hline 27 & Anti-CD8 and anti-CD86 & 9 & Jin et al. (2005) \\
\hline 24 & Anti-CD86 & 8 & Zhao et al. (2007) \\
\hline 28 & Anti-CD86 & 7 & Zhu et al. (2005) \\
\hline 20 & Cyclosporin A (5 mg/kg) & 3 & Du et al. (2007) \\
\hline 27 & Cyclosporin A (5 mg/kg) & 16 & Li et al. (2009) \\
\hline $27-30$ & Adenovirus-driven overexpression of Ctla 4 on day 5 & 12 & Li et al. (2009) \\
\hline 23 & i. vag. injection TGF $\beta$ day 0.5 & 12 & Clark et al. (2008b) \\
\hline 70 & Interleukin 10 (IL10) from culture supernatant on days 6,8 , and 10 & 5 & Chaouat et al. (1995) \\
\hline 35 & Tumor necrosis factor (TNF) inhibitor (Pentoxifillin) on days 6,8 , and 10 & 20 & Chaouat et al. (1995) \\
\hline 35 & Anti $\gamma$-interferon early in gestation & 15 & Chaouat et al. (1995) \\
\hline 35 & TNF inhibitor + anti $\gamma$-IFN early in gestation & 10 & Chaouat et al. (1995) \\
\hline $46-55$ & IL3 on days $6.5-10.5$ & $19-28$ & Chaouat et al. (1990) \\
\hline $35-40$ & Interferon- $\tau$ & $5-10$ & Chaouat et al. (1995) \\
\hline 43 & IL2 daily for 10 days from 4 days before mating & 15 & Chen et al. (2013) \\
\hline 31 & $\mathrm{C} 57 \mathrm{Bl} / 6$ male spleen and thymus cells & 8 & Chavez et al. (1987) \\
\hline 31 & DBA male spleen and thymus cells & 12 & Chavez et al. (1987) \\
\hline 27 & $\mathrm{~T}$ cells from anti-B7-treated nonpregnant mice on day 4 of gestation & 11 & Jin et al. (2004) \\
\hline $18-20$ & $\begin{array}{l}\mathrm{CD} 4+\mathrm{CD} 25+\mathrm{T} \text { cells from day } 14 \mathrm{CBA} \times \text { Balb/c females on } \\
\text { days } 0-2 \text { of pregnancy }\end{array}$ & $\sim 0$ & $\begin{array}{l}\text { Zenclussen et al. (2005) } \\
\text { and Wafula et al. } \\
\text { (2009) }\end{array}$ \\
\hline 20 & $\begin{array}{l}\mathrm{CD} 4+\mathrm{CD} 25+\mathrm{T} \text { cells from day } 14 \mathrm{CBA} \times \mathrm{Balb} / \mathrm{c} \text { females on } \\
\text { days } 0-2 \text { of pregnancy }+ \text { anti-CTLA4 on days } 0,3,6 \text {, and } 9 \text { of pregnancy }\end{array}$ & $\sim 0$ & Wafula et al. (2009) \\
\hline 29 & $\begin{array}{l}\text { Fresh CD4 }+ \text { CD } 25+T \text { cells from nonpregnant CBA females on } \\
\text { days } 1-4 \text { of pregnancy }\end{array}$ & $19-22$ & Yin et al. (2012) \\
\hline 29 & $\begin{array}{l}\text { In vitro expanded CD4 }+\mathrm{CD} 25+\mathrm{T} \text { cells from nonpregnant } \\
\text { CBA females on days } 1-4 \text { of pregnancy }\end{array}$ & $10-12$ & Yin et al. (2012) \\
\hline 30 & $3 \times 10^{5}$ regulatory $B$ cells on day 0 of pregnancy & $\sim 0$ & Jensen et al. (2013) \\
\hline 20 & Lipopolysaccharide (LPS) 2 weeks before mating & 9 & Baines et al. (1996) \\
\hline 20 & Complete Freund's adjuvant 2 weeks before mating & 10 & Baines et al. (1996) \\
\hline 43 & Flt- $3^{\$}$ on day 6 before mating & 14 & Chen et al. (2013) \\
\hline 29 & Anti-Crry lg & 10 & Girardi et al. (2006) \\
\hline 29 & Anti-C5a & 10 & Girardi et al. (2006) \\
\hline 29 & C5a receptor antagonist peptide & 10 & Girardi et al. (2006) \\
\hline 30 & Prevastatin & 10 & Redecha et al. (2009) \\
\hline \multicolumn{4}{|c|}{ Increased resorption rate } \\
\hline 19 & Second experiment, same publication (change housing) & 37 & Clark et al. (1994) \\
\hline 19 & Third experiment, same publication (change housing) & 45 & Clark et al. (1994) \\
\hline 43 & TNF $\sim$ day 5.5 & 52 & Chaouat et al. (1990) \\
\hline 28 & TNF day 7 & 98 & Chaouat (1994) \\
\hline 43 & TNF $\sim 9.5$ & 88 & Chaouat et al. (1990) \\
\hline 43 & TNF $\sim 13.5$ & 67 & Chaouat et al. (1990) \\
\hline 28 & $\gamma$-IFN $\sim$ day 7 & 75 & Chaouat (1994) \\
\hline 30 & IL2 day 7 & 65 & Chaouat (1994) \\
\hline 50 & Anti-IL10 on days 6,8 , and 10 & 80 & Chaouat et al. (1995) \\
\hline 19 & Anti-GMCSF on day 7.5 & 38 & Clark et al. (1994) \\
\hline$?$ & LPS on day 0.5 & 18 & Clark et al. (2008b) \\
\hline 38 & LPS day 7 & 100 & Chaouat et al. (1990) \\
\hline $28-30$ & LPS $\sim$ day 7 & $55-58$ & Chaouat (1994) and Clark \\
\hline
\end{tabular}


Table 2 Continued.

\begin{tabular}{|c|c|c|c|}
\hline $\begin{array}{l}\text { Baseline resorption } \\
\text { rate* }(\%)\end{array}$ & Manipulation (injection unless noted) & $\begin{array}{c}\text { Resulting } \\
\text { resorption } \\
\text { rate* }(\%)\end{array}$ & References \\
\hline 24 & Poly I:C & 65 & Duclos et al. (1994) \\
\hline 30 & Balb/c $\times$ DBA recombinant inbred strains $\mathrm{L}, \mathrm{E}$ & $50-62$ & Kiger et al. (1985) \\
\hline $10-23$ & Sound stress for $24 \mathrm{~h}$ on day 5.5 & 44 & Prados et al. (2011) \\
\hline 10 & Sound stress for $24 \mathrm{~h}$ on day 5.5 & 30 & Arck et al. (1999) \\
\hline 33 & Anti-CD25 antibody on day 1 & 67 & Chen et al. (2013) \\
\hline 10 & Anti-T cell receptor antibody on day 5.5 & $\sim 100$ & Arck et al. (1997) \\
\hline 11 & Anti- $\gamma \delta$ T cell antibody on day 8.5 & $44-48$ & Arck et al. (1999) \\
\hline 19 & Anti-CD8 antibody on day 6.5 & 60 & Clark et al. (1994) \\
\hline 45 & Anti-CD8 antibody on day 6.5 & 78 & Clark et al. (1994) \\
\hline 20 & $\begin{array}{l}\mathrm{CD} 4+\mathrm{CD} 25+\mathrm{T} \text { cells from day } 14 \mathrm{CBA} \times \mathrm{Balb} / \mathrm{c} \text { females on } \\
\text { days } 0-2 \text { of pregnancy }+ \text { anti-PD } 1 \text { on days } 0,3,6 \text {, and } 9 \text { of pregnancy }\end{array}$ & $\sim 30$ & Wafula et al. (2009) \\
\hline \multicolumn{4}{|c|}{ No change in resorption rate } \\
\hline 25 & Prior delivery with Balb/c males 6 weeks before mating & & Baines et al. (1996) \\
\hline 20 & Second pregnancy with rapid re-mating ( 7 days) after delivery & & Baines et al. (1996) \\
\hline $20-35$ & CBA male spleen cells 7 days before mating & & Clark et al. (2013) \\
\hline $20-35$ & DBA male spleen cells 7 days before mating & & Clark et al. (2013) \\
\hline $20-35$ & Nonpregnant female Balb/c spleen cells i.p. 7 days before mating & & Kiger et al. (1985) \\
\hline $20-35$ & Male Balb/b or Balb/k spleen cells i.p. 7 days before mating & & Kiger et al. (1985) \\
\hline 27 & Balb/c spleen cells 8 weeks before mating & & Baines et al. (1996) \\
\hline 20-35 & Balb/c spleen cells pre-incubated with DBA seminal plasma & & Clark et al. (2013) \\
\hline 11 & Anti-Vgamma 1.1, anti-Vdelta 6 antibody on day 5.5 & & Arck et al. (1999) \\
\hline 30 & Spleen cells from Balb/c $\times$ DBA recombinant inbred strains $M, J, D$ & & Kiger et al. (1985) \\
\hline
\end{tabular}

${ }^{*}$ Rounded to nearest percent. ${ }^{*}$ Administration of Balb/c spleen cells works to decrease resorptions up to 4 days after mating. ${ }^{\$}$ fms-related tyrosine kinase 3. 'LPS is used to "boost" the resorption rate in matings done in clear rooms but it is unclear what the baseline rate is.

before mating with DBA/2 males increased the apparent ability for placental cells to suppress NK cell-mediated lysis in this model, several normal mating combinations expressed similar low levels of such suppression to the unmanipulated CBA/J mothers (Chaouat et al. 1985). An additional finding related to the protective effect of immunization was the elaboration of an anti-paternal MHC antibody or serum protein that possessed a suppressive factor, underlying the complexity of the 'protective' effect of immunization (Chaouat et al. 1985).

\section{T helper cytokine biology and the 'CBA/J $\times D B^{\prime}$ ' model}

Very early studies of the $\mathrm{CBA} / \mathrm{J} \times \mathrm{DBA} / 2$ model had suggested that two types of immune response were present in the placenta and decidua, one protective and the other harmful. The idea that successful pregnancy was dependent on the limitation of maternal immunity evolved to include the idea that pregnancy was dependent on regulating/suppressing the expression of $\mathrm{T}$ helper 1 (TH1)-type immunity and enhancing TH2-type immune responses (Lin et al. 1993, Krishnan et al. 1996). This idea was supported by several studies on the $\mathrm{CBA} / \mathrm{J} \times \mathrm{DBA} / 2$ model where investigators observed deficiency in cytokines such as interleukin 4 (IL4) and IL10 in fetal-placental units of $\mathrm{CBA} / \mathrm{J} \times \mathrm{DBA} / 2$ pregnancies compared with normal pregnancies in unrelated strains (Chaouat et al. 1995) and increased TH1-type systemic responsiveness of CBA/J maternal T cells (Jin et al. 2006). Moreover administration of TH1 cytokines alone, such as tumor necrosis factor (TNF) and $\gamma$-interferon, greatly increased resorption rates (Chaouat 1994). Further, the investigators observed that post-implantation antibody-mediated depletion of IL10 resulted in increased pregnancy loss, while administration of exogenous IL10 had the opposite effect (Chaouat et al. 1995). Related studies have also suggested that enhanced expression of these cytokines is a mechanism by which pre-pregnancy immunization of $\mathrm{CBA} / \mathrm{J}$ females decreases the resorption rate subsequently observed (Chaouat et al. 1995). The issue continued to be studied and yielded data suggesting that $\mathrm{CBA} / \mathrm{J} \times \mathrm{DBA} / 2$ pregnancies, compared with 'non-resorbing' $\mathrm{CBA} / \mathrm{J} \times$ Balb/c, produced CD4 T cells with adhesion molecules consistent with a TH2-like phenotype (Jiang et al. 2009). Demonstration of normal pregnancy, despite immunization against paternal antigens in mice deficient in IL4 (Bonney 2001) and IL10 (Bonney \& Onyekwuluje 2004) (among others), and several studies showing the importance of TH1-type cytokines in normal placental development and decidual function (e.g. Ashkar et al. (2000), Chaouat et al. (2002), and Monk et al. (2005)), suggested that a $\mathrm{TH} 1 / \mathrm{TH} 2$ paradigm alone was too simplistic to explain resorption in the $\mathrm{CBA} / \mathrm{J} \times \mathrm{DBA} / 2$ model in particular and maternal tolerance in general (Chaouat et al. 2004, Mas et al. 2008).

\section{Alternative models of immune system activation and the 'CBA/J $\times$ DBA' model}

Although the $\mathrm{CBA} / \mathrm{J} \times \mathrm{DBA} / 2$ model delineated complexities of the cytokine milieu present at the maternal-fetal interface, use of the model continued to support the fundamental theory of self/nonself discrimination and the 
critical dependence of successful pregnancy on the regulation, limitation, and deviation (toward certain classes of response) of local or systemic maternal immunity. The mid-1990s brought forth alternative theories about the role of tissues, antigens, and the immune system in the generation of T cell activation. One model (Matzinger 1994) suggested that it was not nonself recognition, but the presence of metabolic dysfunction, necrosis, or other fundamental tissue or cellular-level dysregulation that generated the signals to initiate the immune response. These 'Danger' signals in the course of this process could lead to activation of local cells whose primary purpose was processing and presentation of antigen (professional antigen-presenting cells (Matzinger 1994) and the generation of both primary and co-stimulatory signals used by T cells to achieve full activation. A critical assertion of the theory was that as long as a tissue was functioning normally, and not undergoing any stress, damage, or fundamental dysregulation, there was no need to suppress, limit, or deviate the immune system in order to prevent auto-reactive T cell-mediated damage. This theory suggested that this should be true for the fetus, even though the fetus might be 'semi-allogeneic' to the mother (Bonney 2007). An alternative to the Danger theory suggested that immune system activation was primarily generated through the recognition of evolutionary or infectious nonself (Janeway 1992) but kept many tenets of self/nonself discrimination theory. This later alternative posited that immune system activation occurred based on the recognition of molecular patterns that comprised bacterial products (Janeway et al. 1996). Investigators working with the $\mathrm{CBA} / \mathrm{J} \times \mathrm{DBA} / 2$ model appeared to meld the specifics of the two models to explain some of the peculiar findings observed in DBA/2-mated CBA/J mice.

One such finding was the wide variation in resorption rate, which appeared to be increased in dirtier conventional housing vs 'clean' housing (Clark et al. 1997). It was further observed that injection of lipopolysaccharide (LPS) also induced resorption when given i.v. for 7 days after mating (Chaouat et al. 1990), and that injection of inflammatory cytokines, such as TNF, mimicked (Chaouat et al. 1990) and augmented (Chaouat 1994, Clark et al. 2004) the LPS response. However, this effect was also observed in nonabortion-prone matings, even if to a lesser extent (Chaouat et al. 1990). When it was later observed that the effect of LPS and other molecules on resorptions was indeed dependent on Toll-like receptor (TLR) signaling (Clark et al. 2003), this and related mechanisms were thought to comprise a 'third signal' or pathway by which resorptions could occur in this mating combination. The finding that immunization with Balb/c spleen could counteract resorption due to early LPS- or TNF-related administration, but not preterm delivery due to late administration of the molecules in DBA/2-mated CBA/J mice (Chaouat 1994), suggested to some that resorption was in part due to mechanisms that were unique to 'Danger' and fell within the context of failed maternal tolerance in the classical (self/nonself) sense.

Another observation generated by this mating combination yet difficult to explain by classic immune theory was that exposure to sound stress for $24 \mathrm{~h}$ on day 5.5 of pregnancy increased the resorption rate (Arck et al. 1995). This was associated with the expression of inflammatory cytokines (Arck et al. 1995), adhesion molecules important in lymphocyte trafficking (Prados et al. 2011), and a decrease in suppressive molecules mediating T cell metabolism (Blois et al. 2005), and was ameliorated by administration of Balb/c spleen cells. As these studies developed, it was hypothesized that sound stress changed intestinal permeability and was similar to systemic injection with LPS (Clark et al. 2004). Although this was supported by other studies in the literature (Bijlsma et al. 2001), it was not definitively proven in this model. It could be said that the investigators using the $\mathrm{CBA} / \mathrm{J} \times \mathrm{DBA} / 2$ model did not see these observations as strongly arguing against either self/nonself discrimination theory or its corollary, that lack of inherent suppression or limitation of the maternal immune system was the primary pathway by which resorptions occurred in this model. Work continued to find other mechanisms supportive of a suppressive process.

However, according to the 'Danger' theory, signals through TLR and other molecules recognizing pathogenassociated molecular patterns comprise a particular subset of the wide range of possible 'Danger' signals. Potentially any molecule that is deregulated in expression, location, or configuration (folding, Seong \& Matzinger (2004)) could, in the right context during pregnancy (Bonney 2007), signal that 'Danger' is occurring in a cell or tissue and activate local antigen-presenting cells. Even complement itself could serve as a Danger signal (Kwan et al. 2012). From this perspective, the task of understanding the high resorption rate present in the $\mathrm{CBA} / \mathrm{J} \times \mathrm{DBA} / 2$ model might be framed as having two components: i) the effort to incorporate existing data that suggest fundamental dysregulation in the critical tissues present at the maternal-fetal interface and ii) the search to find mechanisms by which this dysregulation occurs.

Published observations have noted abnormal decidual vascular modification (Dixon et al. 2006), altered expression of VEGF and its receptor (Girardi et al. 2006), decreased blood perfusion (Redecha et al. 2009), decreased trophoblast giant cells (Girardi et al. 2006), increased fibrin deposition (Redecha et al. 2009), increased tissue factor expression (Redecha et al. 2009), and increased thrombin activity disregulation (Clark et al. 1998). Increased placental/decidual expression of complement component $\mathrm{C} 3$ is also an element of the model that is thought to promote increased influx of macrophages and neutrophils and local expression of TNF (Girardi et al. 2006). Many of these abnormalities suggest comparison with the innate immune response following ischemiareperfusion injury (Zhang \& Carroll 2007). Moreover, this 
mating combination suffers from increased oxidative stress that can be remediated by overexpression of heme-oxygenase-I (Zenclussen et al. 2006). In addition, there is evidence suggesting a differential expression of a placental ATPase in this combination compared with normal or syngeneic Balb/c matings (Jaiswal et al. 2011), and this is correlated with altered macrophage function in the placenta. However, while LPS can cause this altered ATPase expression, it is not clear whether altered macrophage function drives or is driven by altered ATPase expression in this abortion-prone model (Jaiswal et al. 2011). Early (Muzikova \& Clark 1995) and later studies (Brown et al. 2013) also suggest that abnormalities existing in the $\mathrm{CBA} / \mathrm{J}$ decidua and its interaction with the developing embryo are the prime movers of the pathology related to these pregnancies, and this idea is supported by the fact that 'reverse' matings between DBA/2 females and $\mathrm{CBA} / \mathrm{J}$ males are considered normal (Dixon et al. 2006). Finally, this mating combination suffers from a fundamental disorganization of DNA methylation (Brown et al. 2013). Thus the CBA/J $\times D B A / 2$ mating combination is abnormal on many levels potentially independent of primary immune system disregulation.

Since the original description of increased pregnancy failure in $\mathrm{CBA} / \mathrm{J}$ dams mated to DBA/2 males, most reports have focused on the pregnancy failure aspect of the model and have not commented about a maternal phenotype. A 2010 report (Ahmed et al. 2010) notes that $\mathrm{DBA} / 2$-mated $\mathrm{CBA} / \mathrm{J}$ females develop significant proteinuria by day 12 of gestation, indicating some sort of pregnancy-induced renal damage. Light and electron microscopic analysis of the maternal kidneys of these dams showed evidence of endothelial injury and diminished blood flow, consistent with the proteinuria. Although DBA/2-mated $\mathrm{CBA} / \mathrm{J}$ dams did not develop elevated blood pressure during pregnancy, they were markedly more sensitive to a challenge with angiotensin II than were control animals, indicating a generalized effect of pregnancy on the maternal vasculature. This was further corroborated by ex vivo studies showing a stronger response of the aortic ring to angiotensin II in DBA/2-mated CBA/J dams. These studies highlight a potential fundamental and systemic dysregulation underlying this mating.

\section{Regulatory T cells: resurgence of immune modulation and the 'CBA/J $\times$ DBA' model}

The resurrection of the suppressor T cell as a CD4+ $\mathrm{CD} 25+$ regulatory $\mathrm{T}$ cell expressing the Forkhead transcription factor Foxp3 (Fontenot et al. 2003) opened a new avenue for those who sought to explain, in the context of self/nonself discrimination, why there was increased resorption in the $\mathrm{CBA} / \mathrm{J} \times \mathrm{DBA} / 2$ model and why pre-pregnancy immunization with Balb/c spleen cells, exposure to Balb/c seminal plasma
(Clark et al. 2013), or administration of specific cytokines such as transforming growth factor $\beta$ (TGF $\beta)$ (Clark et al. $2008 b$ ) decreased the resorption rate.

Several lines of evidence suggested that 'naturally' occurring $T$ regs were a specific lineage, bearing Foxp3, highly dependent on IL2, and expressing molecules such as CD25 and CTLA4. It is thought that these cells resulted from having a high affinity for and seeing 'self' antigen in the thymus. The now-named 'tT-reg' (Abbas et al. 2013) were thought to leave the thymus into the periphery as fully mature and functional cells, many expressing the memory cell markers (e.g. CD $44^{\text {hi }}, \mathrm{CD} 62 \mathrm{~L}^{\mathrm{lo}}$ ) that could suppress other subsets of self-reactive T cells (reviewed in Sakaguchi et al. (2008)). In addition, investigators have observed that exposure of naïve $T$ cells in the periphery to antigen in the context of TGF $\beta$, IL2, retinoic acid, or signals via Fms-related tyrosine kinase 3 ligand, could produce a 'pT reg' (Abbas et al. 2013) T cell with regulatory function (Sakaguchi et al. 2008).

In contrast, exposure to antigen in the context of TGF $\beta$ and IL6 could generate TH17 T cells. The stability of $\mathrm{T}$ reg and TH17 phenotypes may not be strong (Sakaguchi et al. 2013), as conversion can occur in the context of hormonal disregulation (Li et al. 2013), severe infection (Rowe et al. 2012a, Zhang et al. 2012), and TLR signaling (Nyirenda et al. 2011). Understanding the various mechanisms by which thymic or peripheral $T$ regs exert their effects on T cells is ongoing, and can include suppression of cytokine production and proliferation (Thornton \& Shevach 1998), direct killing (Abdulahad et al. 2011), and modulation of function (Collison et al. 2009, Zelinskyy et al. 2013).

Regulatory $\mathrm{T}$ cell dysfunction has been implicated for many years in mouse models of premature ovarian failure and autoimmune oophoritis and other reproductive track-related autoimmune diseases (Bonomo et al. 1995, Tung \& Teuscher 1995). Investigators observed that administration of CD4 + CD25+ spleen and thymus cells from a day 14 normally pregnant (Balb/c-mated) CBA/J female to a DBA/2-mated CBA/J female on days $0-2$ of pregnancy decreased the resorption rate (Zenclussen et al. 2005, Wafula et al. 2009), while antibody to CD25 (Chen et al. 2013) increased the rate of resorption and blockade of PD1 (Wafula et al. 2009) and abrogated the protective effect of $\mathrm{T}$ reg administration. These experiments did not delineate the specificity of the regulatory $\mathrm{T}$ cell pool, and indeed it has been shown that CD4 + CD25 + cells with regulatory capacity, potentially naturally occurring, thymus-derived T regs, expand during syngeneic as well as allogeneic pregnancies (Aluvihare et al. 2004, Teles et al. 2013). Moreover, like many of the experiments done on this model, the T regulatory administration was not done in a pregnancy where neither the role of the specificity nor the level of target paternal antigen expression (e.g. a CBA/J $\times(\mathrm{CBA} / \mathrm{J} \times \mathrm{DBA} / 2 \mathrm{~F} 1)$ backcross) on resorption could be assessed. 
Experiments in this model have suggested that in vitro activated and expanded CD25 + CD4 + vs naïve T regs were effective in decreasing resorption (Yin et al. 2012). In other models, it has also been observed that shared expression of antigen in the maternal thymus and the fetus markedly enhances antigen-specific $\mathrm{T}$ reg proliferation in the uterine-draining lymph nodes (Chen et al. 2013). However, these observations do not prove that exposure to a specific antigen is directly related to the generation of $\mathrm{T}$ reg function and decreased resorptions specifically in antigen-expressing sites. Moreover, while expansion of such cells is thought to occur at the level of the uterine draining lymph nodes (Teles et al. 2013), it is not clear where and to what extent the transferred C25+ $\mathrm{CD} 4+$ cells traffic in the process of decreasing resorptions in this model.

Does the presence of $\mathrm{T}$ regs and the effects of their modification prove the self/nonself theory, or that pregnancy is critically dependent on suppression, deviation, or limitation of the maternal immune system? Are T regs critical to successful semi-allogeneic pregnancy? While many users and proponents of the $\mathrm{CBA} / \mathrm{J} \times \mathrm{DBA} / 2$ model may still hold to this thinking (Chen et al. 2013), there is an alternative. For example, it is known that T cells with regulatory function and memory are generated by antigen exposure in the right context (TGF $\beta$, etc.) during pregnancy (Rowe et al. 2012b). It could be said that these cells are essentially another flavor of $\mathrm{T}$ cells which have been revealed by the experimental context generated. Moreover, they along with their partner TH17 cells represent a similar balance of reactivity dependent on tissue need and tendency (Matzinger \& Kamala 2011) as that ascribed to the TH2-TH1 paradigm of some years ago. It is even possible, if not likely, that there are several flavors of $\mathrm{T}$ reg cells, perhaps ones that specifically regulate certain types of inflammation (Bizargity et al. 2009). These cells are not the 'Sang Real' of tolerance. Danger, for example, in the form of intracellular infection, can decrease the presence and activity of $\mathrm{T}$ regs and generate anti-fetal immunity (Rowe et al. 2012a). While such a situation is obviously harmful to the fetus, it is protects the mother against infection and other losses associated with carrying a potentially abnormal fetus to term.

Another possibility, that includes naturally occurring Tregs, is that these cells exist to limit 'collateral damage' (Thangavelu et al. 2013) or 'bystander effect' (Anderson 2006). In this vein, the original Danger model dealt with the generation of auto-reactive T cells in the context of an immune response to infection by suggesting that tissues, especially large and fast-growing tissues, could essentially 'out run' the effects of auto-reactive T cells (Matzinger 1994), while small, slow growing tissues could not (Anderson et al. 2001). It is possible then to see $\mathrm{T}$ regs, especially the naturally occurring ones which tend to be tissue specific (del Rio et al. 2011), as a possible mechanism by which specific tissues may 'out run' bystander auto-reactive T cell generation. Self/ nonself theory may strongly depend on the existence of $\mathrm{T}$ regs. Although they are not critical, they can be incorporated into to this alternative theory.

\section{Driving where? The future of the 'CBA/J $\times$ DBA' model}

The recent observation that there is a very pronounced maternal renal/vascular phenotype in the $\mathrm{CBA} / \mathrm{J} \times \mathrm{DBA} / 2$ model (Ahmed et al. 2010) and that the model relates only to first pregnancies (Singh et al. 2011) has several important implications. First, the fact that the mothers are so profoundly affected by the abnormal pregnancies strongly implies that the $\mathrm{CBA} / \mathrm{J} \times \mathrm{DBA} / 2$ model should not be interpreted as being a model for most human first trimester miscarriages. In the majority of human miscarriages, there is no evidence of any sort of maternal renal/vascular disease although pregnancy loss can be the first manifestation of disease (Yin et al. 2013). In fact, pregnancy failure secondary to severe maternal illness caused by the pregnancy itself is relatively rare, and the pregnancy 'failures' are usually the consequence of deliberate termination procedures. Secondly, the fact that the $\mathrm{CBA} / \mathrm{J} \times \mathrm{DBA} / 2$ model relates almost entirely to first pregnancies makes one question its relevance to recurrent pregnancy loss in humans. The generally understood concept behind recurrent pregnancy loss is that there is some process at the maternal-fetal interface that similarly affects all pregnancies. If the pathophysiological mechanism in the $\mathrm{CBA} / \mathrm{J} \times \mathrm{DBA} / 2$ model was similar to the human situation, then women who had had one pregnancy loss would be expected to have a diminished probability for a subsequent pregnancy to end in miscarriage. In fact, the evidence suggests that women who have had one miscarriage have a somewhat increased probability for loss in a subsequent pregnancy (Regan et al. 1989). On this basis, there may be concern regarding the potential to gain general understanding of most human recurrent miscarriages.

However, the observations generated in the $\mathrm{CBA} / \mathrm{J} \times$ $\mathrm{DBA} / 2$ model show the capacity for the maternal immune system to respond to signals presented by its environment. Taken together the observations that: i) T regs can be increased either through administration of third-party spleen cells or other exposure to seminal plasma antigens, ii) there is a significant amount of tissue-level metabolic and other dysregulation, and iii) resorption is associated with a significant innate immune response (neutrophils, macrophages, dendritic cells, inflammatory cytokines) suggests that a likely role for $\mathrm{T}$ cells with regulatory function in this model is as modulators of innate immunity. This is in keeping with what has been observed in the nonpregnant state (Maloy et al. 2003), suggested by studies of the regulation of LPS-induced preterm birth in a syngeneic 
mouse mating (Bizargity et al. 2009), and inferred from studies of human preterm birth (Ito et al. 2010). In this light, the model could be very useful in understanding the intricate metabolic and developmental programming particular to the maternal-fetal interface, further delineation of the 'Danger' signal, or 'signal 0 ', and further understanding of the complex and intricate mechanisms by which adaptive immunity might exert feedback control of innate immunity. This model could also examine the role of the recently 're-recognized' innate lymphoid cells, including natural killer T cells (Boyson et al. 2006) and the non-T cell receptor expressing counterparts of known TH cell subsets (Lane et al. 2012, Spits \& Cupedo 2012). Moreover, recent data suggest that transfer of CD19+ CD5 + CD1d + B cells i.v., with concomitant increase in such cells in the spleen, also decreases resorptions (Jensen et al. 2013), and further examination of this cell type is warranted.

The mid-1990s witnessed the use $\mathrm{T}$ cell receptor transgenic mice in the study of maternal tolerance (Tafuri et al. 1995). Since then several investigators have produced evidence in these systems that the maternal T cells are 'aware' that the host is pregnant (Bonney et al. 2011), undergo proliferation and death (Norton et al. 2010), and are able to respond to fetal antigens (Erlebacher et al. 2007, Norton et al. 2010). For most mice, neither the increased presence of $T$ cells specific for fetal antigen nor manipulations to increase fetal antigen-specific $\mathrm{T}$ cell proliferation or function has resulted in specific pregnancy loss (see review by Moldenhauer et al. (2010)). The CBA/J $\times D B A / 2$ model has perhaps encouraged the expanded use of TCR transgenic mice. In one particular model, baseline levels of the overall fetal resorption rate are low, despite a high frequency of maternal $T$ cells specific for an antigen transgenically expressed on the fetus (Chen et al. 2013). Immunization against this antigen along with depletion of $\mathrm{T}$ regs with antibody to $\mathrm{CD} 25$ increased overall resorption several fold; however, the role of the level of fetal antigen expression in resorbed vs non-resorbed fetuses is yet to be delineated (Chen et al. 2013). It might be very useful to generate a TCR transgenic mouse model within the CBA/J (expressing maternal specific anti-fetal $T$ cells), DBA/2 (expressing specific fetal antigen), and Balb/c (expressing fetal antigen) backgrounds. If there is a specific fetal antigen that drives the resorptions in the $\mathrm{CBA} / \mathrm{J} \times \mathrm{DBA} / 2$ model, it needs to be found in order to do similar experiments based on responsiveness to that particular antigen.

More important than the generation of specific tools, however, is the willingness to engage in experimentation with the model in the context of evolving theory of how the immune system chooses between activation and tolerance. Although several theories that might be considered (Anderson et al. 2001, Zinkernagel \& Hengartner 2004, Anderson 2006, Cohn 2013), we have herein give one possible interpretation of the data derived from the $\mathrm{CBA} / \mathrm{J} \times \mathrm{DBA} / 2$ model that would allow for alternatives to fundamental self/nonself discrimination theory as the basis for maternal tolerance. We posit that with minds open to this and other alternatives, we will be able to use the $\mathrm{CBA} / \mathrm{J} \times \mathrm{DBA} / 2$ model to continue to produce observations that enhance our understanding of the critically important biology of successful pregnancy and its complications.

\section{Declaration of interest}

The authors declare that there is no conflict of interest that could be perceived as prejudicing the impartiality of the review.

\section{Funding}

This work was in part funded by NIH RO1 HD043185, R21AI081000, and P20 RR021905, the Department of Obstetrics, Gynecology and Reproductive Sciences, University of Vermont College of Medicine, and the Vermont Center for Immunology and Infectious Disease.

\section{Acknowledgements}

The authors acknowledge all of the years of hard work done by our colleagues and apologize for observations not cited due to space considerations. They thank Jonathon E Boyson for review of this work and for helpful suggestions.

\section{References}

Abbas AK, Benoist C, Bluestone JA, Campbell DJ, Ghosh S, Hori S, Jiang S, Kuchroo VK, Mathis D, Roncarolo MG et al. 2013 Regulatory T cells: recommendations to simplify the nomenclature. Nature Immunology 14 307-308. (doi:10.1038/ni.2554)

Abdulahad WH, Boots AM \& Kallenberg CG 2011 FoxP3 + CD4 + T cells in systemic autoimmune diseases: the delicate balance between true regulatory T cells and effector Th-17 cells. Rheumatology 50 646-656. (doi:10.1093/rheumatology/keq328)

Ahmed A, Singh J, Khan Y, Seshan SV \& Girardi G 2010 A new mouse model to explore therapies for preeclampsia. PLoS ONE 5 e13663. (doi:10.1371/journal.pone.0013663)

Aluvihare VR, Kallikourdis M \& Betz AG 2004 Regulatory T cells mediate maternal tolerance to the fetus. Nature Immunology 5 266-271. (doi:10.1038/ni1037)

Anderson CC 2006 Time, space and contextual models of the immunity tolerance decision: bridging the geographical divide of Zinkernagel and Hengartner's 'Credo 2004'. Scandinavian Journal of Immunology 63 249-256. (doi:10.1111/j.1365-3083.2006.01742.x)

Anderson JM \& Benirschke K 1964 Maternal tolerance of foetal tissue. BMJ 1 1534-1535. (doi:10.1136/bmj.1.6177.1534)

Anderson CC, Carroll JM, Gallucci S, Ridge JP, Cheever AW \& Matzinger P 2001 Testing time-, ignorance-, and danger-based models of tolerance. Journal of Immunology 166 3663-3671.

Arck PC, Merali FS, Manuel J, Chaouat G \& Clark DA 1995 Stress-triggered abortion: inhibition of protective suppression and promotion of tumor necrosis factor- $\alpha$ (TNF- $\alpha$ ) release as a mechanism triggering resorptions in mice. American Journal of Reproductive Immunology 33 74-80. (doi:10.1111/j.1600-0897.1995.tb01141.x)

Arck PC, Ferrick DA, Steele-Norwood D, Croitoru K \& Clark DA 1997 Murine T cell determination of pregnancy outcome: I. Effects of strain, 
$\alpha \beta \mathrm{T}$ cell receptor, $\gamma \delta \mathrm{T}$ cell receptor, and $\gamma \delta \mathrm{T}$ cell subsets. American Journal of Reproductive Immunology 37 492-502. (doi:10.1111/j.16000897.1997.tb00265.x)

Arck PC, Ferrick DA, Steele-Norwood D, Egan PJ, Croitoru K, Carding SR, Dietl J \& Clark DA 1999 Murine T cell determination of pregnancy outcome. Cellular Immunology 196 71-79. (doi:10.1006/cimm.1999.1535)

Ashkar AA, Di Santo JP \& Croy BA 2000 Interferon $\gamma$ contributes to initiation of uterine vascular modification, decidual integrity, and uterine natural killer cell maturation during normal murine pregnancy. Journal of Experimental Medicine 192 259-270. (doi:10.1084/jem.192.2.259)

Baines MG, Haddad EK, Pomerantz DK \& Duclos AJ 1994 Effects of sensory stimuli on the incidence of fetal resorption in a murine model of spontaneous abortion: the presence of an alien male and postimplantation embryo survival. Journal of Reproduction and Fertility 102 221-228. (doi:10.1530/jrf.0.1020221)

Baines MG, Duclos AJ, de Fougerolles AR \& Gendron RL 1996 Immunological prevention of spontaneous early embryo resorption is mediated by non-specific immunosimulation. American Journal of Reproductive Immunology 35 34-42. (doi:10.1111/j.1600-0897.1996.tb00006.x)

Bijlsma PB, van Raaij MT, Dobbe CJ, Timmerman A, Kiliaan AJ, Taminiau JA \& Groot JA 2001 Subchronic mild noise stress increases HRP permeability in rat small intestine in vitro. Physiology \& Behavior 73 43-49. (doi:10.1016/S0031-9384(01)00424-3)

Bizargity P, Del Rio R, Phillippe M, Teuscher C \& Bonney EA 2009 Resistance to lipopolysaccharide-induced preterm delivery mediated by regulatory T cell function in mice. Biology of Reproduction 80 874-881. (doi:10.1095/biolreprod.108.074294)

Blois S, Alba Soto CD, Olmos S, Chuluyan E, Gentile T, Arck PC \& Margni RA 2004 Therapy with dendritic cells influences the spontaneous resorption rate in the CBA/J x DBA/2J mouse model. American Journal of Reproductive Immunology 51 40-48. (doi:10.1046/j.8755-8920.2003.00120.x)

Blois S, Tometten M, Kandil J, Hagen E, Klapp BF, Margni RA \& Arck PC 2005 Intercellular adhesion molecule-1/LFA-1 cross talk is a proximate mediator capable of disrupting immune integration and tolerance mechanism at the feto-maternal interface in murine pregnancies. Journal of Immunology 174 1820-1829.

Bobe P \& Kiger N 1989 Immunogenetic studies of spontaneous abortion in mice. III. Non-H-2 antigens and gestation. Journal of Immunogenetics 16 223-231. (doi:10.1111/j.1744-313X.1989.tb00465.x)

Bobe P, Chaouat G, Stanislawski M \& Kiger N 1986 Immunogenetic studies of spontaneous abortion in mice. II. Antiabortive effects are independent of systemic regulatory mechanisms. Cellular Immunology 98 477-485. (doi:10.1016/0008-8749(86)90306-0)

von Boehmer H, Haas W \& Pohlit H 1978 Cytotoxic T cells recognize male antigen and $\mathrm{H}-2$ as distinct entities. Journal of Experimental Medicine 147 1291-1295. (doi:10.1084/jem.147.4.1291)

Bonney EA 2001 Maternal tolerance is not critically dependent on IL-4. Immunology 103 382-389. (doi:10.1046/j.1365-2567.2001.01239.x)

Bonney EA 2007 Preeclampsia: a view through the danger model. Journal of Reproductive Immunology 76 68-74. (doi:10.1016/j.jri.2007.03.006)

Bonney EA 2013 Demystifying animal models of adverse pregnancy outcomes: touching bench and bedside. American Journal of Reproductive Immunology 69 567-584. (doi:10.1111/aji.12102)

Bonney EA \& Onyekwuluje J 2004 Maternal tolerance to $\mathrm{H}-\mathrm{Y}$ is independent of IL-10. Immunological Investigations 33 385-395. (doi:10.1081/IMM-200032732)

Bonney EA, Shepard MT \& Bizargity P 2011 Transient modification within a pool of CD4 T cells in the maternal spleen. Immunology 134 270-280. (doi:10.1111/j.1365-2567.2011.03486.x)

Bonomo A, Kehn PJ, Payer E, Rizzo L, Cheever AW \& Shevach EM 1995 Pathogenesis of post-thymectomy autoimmunity. Role of syngeneic MLR-reactive T cells. Journal of Immunology $1546602-6611$.

Boyson JE, Nagarkatti N, Nizam L, Exley MA \& Strominger JL 2006 Gestation stage-dependent mechanisms of invariant natural killer $\mathrm{T}$ cell-mediated pregnancy loss. PNAS 103 4580-4585. (doi:10.1073/pnas.0511025103)

Branch DW, Gibson M \& Silver RM 2010 Recurrent miscarriage. New England Journal of Medicine 363 1740-1747. (doi:10.1056/ NEJMcp1005330)

Brown LY, Bonney EA, Raj RS, Nielsen B \& Brown S 2013 Generalized disturbance of DNA methylation in the uterine decidua in the CBA/J $x$ DBA/2 mouse model of pregnancy failure. Biology of Reproduction 1111. (doi:10.1095/biolreprod.113.113142)
Bulmer JN, Morrison L, Longfellow M, Ritson A \& Pace D 1991 Granulated lymphocytes in human endometrium: histochemical and immunohistochemical studies. Human Reproduction 6 791-798.

Burnet FM 1962 The immunological significance of the thymus: an extension of the clonal selection theory of immunity. Australasian Annals of Medicine 11 79-91.

Chaouat G 1994 Synergy of lipopolysaccharide and inflammatory cytokines in murine pregnancy: alloimmunization prevents abortion but does not affect the induction of preterm delivery. Cellular Immunology 157 328-340. (doi:10.1006/cimm.1994.1231)

Chaouat G, Kiger N \& Wegmann TG 1983 Vaccination against spontaneous abortion in mice. Journal of Reproductive Immunology 5 389-392. (doi:10.1016/0165-0378(83)90248-6)

Chaouat G, Kolb JP, Kiger N, Stanislawski M \& Wegmann TG 1985 Immunologic consequences of vaccination against abortion in mice. Journal of Immunology 134 1594-1598.

Chaouat G, Menu E, Clark DA, Dy M, Minkowski M \& Wegmann TG 1990 Control of fetal survival in CBA $x$ DBA/2 mice by lymphokine therapy. Journal of Reproduction and Fertility 89 447-458. (doi:10.1530/jrf.0. 0890447)

Chaouat G, Assal Meliani A, Martal J, Raghupathy R, Elliott JF, Mosmann T \& Wegmann TG 1995 IL-10 prevents naturally occurring fetal loss in the $\mathrm{CBA} \times \mathrm{DBA} / 2$ mating combination, and local defect in IL-10 production in this abortion-prone combination is corrected by in vivo injection of IFN- $\tau$. Journal of Immunology 154 4261-4268.

Chaouat G, Zourbas S, Ostojic S, Lappree-Delage G, Dubanchet S, Ledee N \& Martal J 2002 A brief review of recent data on some cytokine expressions at the materno-foetal interface which might challenge the classical Th1/Th2 dichotomy. Journal of Reproductive Immunology 53 241-256. (doi:10.1016/S0165-0378(01)00119-X)

Chaouat G, Ledee-Bataille N, Dubanchet S, Zourbas S, Sandra O \& Martal J 2004 Reproductive immunology 2003: reassessing the Th1/Th2 paradigm? Immunology Letters 92 207-214. (doi:10.1016/j.imlet.2004.01.011)

Chavez DJ, McIntyre JA, Colliver JA \& Faulk WP 1987 Allogeneic matings and immunization have different effects on nulliparous and multiparous mice. Journal of Immunology 139 85-88.

Chen T, Darrasse-Jeze G, Bergot AS, Courau T, Churlaud G, Valdivia K, Strominger JL, Ruocco MG, Chaouat G \& Klatzmann D 2013 Selfspecific memory regulatory $\mathrm{T}$ cells protect embryos at implantation in mice. Journal of Immunology 191 2273-2281. (doi:10.4049/jimmunol. 1202413)

Christiansen OB, Steffensen R, Nielsen HS \& Varming K 2008 Multifactorial etiology of recurrent miscarriage and its scientific and clinical implications. Gynecologic and Obstetric Investigation 66 257-267. (doi:10.1159/ 000149575)

Christiansen OB, Kolte AM, Dahl M, Larsen EC, Steffensen R, Nielsen HS \& Hviid TV 2012 Maternal homozygocity for a 14 base pair insertion in exon 8 of the HLA-G gene and carriage of HLA class II alleles restricting HY immunity predispose to unexplained secondary recurrent miscarriage and low birth weight in children born to these patients. Human Immunology 73 699-705. (doi:10.1016/j.humimm.2012.04.014)

Clark DA \& McDermott MR 1978 Impairment of host vs graft reaction in pregnant mice. I. Suppression of cytotoxic T cell generation in lymph nodes draining the uterus. Journal of Immunology 121 1389-1393.

Clark DA, McDermott MR \& Szewczuk MR 1980 Impairment of hostversus-graft reaction in pregnant mice. II. Selective suppression of cytotoxic T-cell generation correlates with soluble suppressor activity and with successful allogeneic pregnancy. Cellular Immunology 52 106-118. (doi:10.1016/0008-8749(80)90404-9)

Clark DA, Brierley J, Banwatt D \& Chaouat G 1989 Hormone-induced preimplantation Lyt $2+$ murine uterine suppressor cells persist after implantation and may reduce the spontaneous abortion rate in CBA/J mice. Cellular Immunology 123 334-343. (doi:10.1016/00088749(89)90294-3)

Clark DA, Chaouat G, Mogil R \& Wegmann TG 1994 Prevention of spontaneous abortion in DBA/2-mated CBA/J mice by GM-CSF involves CD8 + T cell-dependent suppression of natural effector cell cytotoxicity against trophoblast target cells. Cellular Immunology 154 143-152. (doi:10.1006/cimm.1994.1064)

Clark DA, Merali FS, Hoskin DW, Steel-Norwood D, Arck PC, Croitoru K, Murgita RA \& Hirte H 1997 Decidua-associated suppressor cells in abortion-prone $\mathrm{DBA} / 2$-mated $\mathrm{CBA} / \mathrm{J}$ mice that release bioactive 
transforming growth factor $\beta 2$-related immunosuppressive molecules express a bone marrow-derived natural suppressor cell marker and $\gamma \delta$ T-cell receptor. Biology of Reproduction 56 1351-1360. (doi:10.1095/ biolreprod56.5.1351)

Clark DA, Chaouat G, Arck PC, Mittruecker HW \& Levy GA 1998 Cytokine-dependent abortion in CBA $\times$ DBA $/ 2$ mice is mediated by the procoagulant $\mathrm{fg} / 2$ prothrombinase [correction of prothombinase]. Journal of Immunology 160 545-549.

Clark DA, Yu G, Arck PC, Levy GA \& Gorczynski RM 2003 MD-1 is a critical part of the mechanism causing Th1-cytokine-triggered murine fetal loss syndrome. American Journal of Reproductive Immunology 49 297-307. (doi:10.1034/j.1600-0897.2003.00045.x)

Clark DA, Manuel J, Lee L, Chaouat G, Gorczynski RM \& Levy GA 2004 Ecology of danger-dependent cytokine-boosted spontaneous abortion in the CBA $\times$ DBA/2 mouse model. I. Synergistic effect of LPS and (TNF- $\alpha+\mathrm{IFN}-\gamma)$ on pregnancy loss. American Journal of Reproductive Immunology 52 370-378. (doi:10.1111/j.1600-0897.2004.00237.x)

Clark DA, Petitbarat M \& Chaouat G 2008a How should data on murine spontaneous abortion rates be expressed and analyzed? American Journal of Reproductive Immunology 60 192-196. (doi:10.1111/j. 1600-0897.2008.00612.x)

Clark DA, Fernandes J \& Banwatt D 2008b Prevention of spontaneous abortion in the CBA $\times$ DBA $/ 2$ mouse model by intravaginal TGF- $\beta$ and local recruitment of CD4+8+ FOXP3 + cells. American Journal of Reproductive Immunology 59 525-534. (doi:10.1111/j.1600-0897. 2008.00582.x)

Clark DA, Rahmati M, Gohner C, Bensussan A, Markert UR \& Chaouat G 2013 Seminal plasma peptides may determine maternal immune response that alters success or failure of pregnancy in the abortionprone CBAxDBA/2 model. Journal of Reproductive Immunology 99 46-53. (doi:10.1016/j.jri.2013.03.006)

Cohn M 2013 Challenging the Tritope Model of T cell receptor structurefunction relationships with classical data on 'super' and 'allo-MHC' antigens. Scandinavian Journal of Immunology 78 313-324. (doi:10. 1111/sji.12092)

Collison LW, Pillai MR, Chaturvedi V \& Vignali DA 2009 Regulatory T cell suppression is potentiated by target T cells in a cell contact, IL-35- and IL-10-dependent manner. Journal of Immunology 182 6121-6128. (doi:10.4049/jimmunol.0803646)

Dixon ME, Chien EK, Osol G, Callas PW \& Bonney EA 2006 Failure of decidual arteriolar remodeling in the $\mathrm{CBA} / \mathrm{J} \times \mathrm{DBA} / 2$ murine model of recurrent pregnancy loss is linked to increased expression of tissue inhibitor of metalloproteinase 2 (TIMP-2). American Journal of Obstetrics and Gynecology 194 113-119. (doi:10.1016/j.ajog.2005.06.063)

Du MR, Dong L, Zhou WH, Yan FT \& Li DJ 2007 Cyclosporin a improves pregnancy outcome by promoting functions of trophoblasts and inducing maternal tolerance to the allogeneic fetus in abortion-prone matings in the mouse. Biology of Reproduction 76 906-914. (doi:10.1095/ biolreprod.106.056648)

Duclos AJ, Pomerantz DK \& Baines MG 1994 Relationship between decidual leukocyte infiltration and spontaneous abortion in a murine model of early fetal resorption. Cellular Immunology 159 184-193. (doi:10.1006/cimm.1994.1306)

Ecker JL, Laufer MR \& Hill JA 1993 Measurement of embryotoxic factors is predictive of pregnancy outcome in women with a history of recurrent abortion. Obstetrics and Gynecology 81 84-87.

Erlebacher A, Vencato D, Price KA, Zhang D \& Glimcher LH 2007 Constraints in antigen presentation severely restrict $\mathrm{T}$ cell recognition of the allogeneic fetus. Journal of Clinical Investigation 117 1399-1411. (doi:10.1172/JCI28214)

Faulk WP \& McIntyre JA 1983 Immunological studies of human trophoblast: markers, subsets and functions. Immunological Reviews 75 139-175. (doi:10.1111/j.1600-065X.1983.tb01094.x)

Faulk WP, Temple A, Lovins RE \& Smith N 1978 Antigens of human trophoblasts: a working hypothesis for their role in normal and abnormal pregnancies. PNAS 75 1947-1951. (doi:10.1073/pnas.75.4.1947)

Finn R, St Hill CA, Govan AJ, Ralfs IG, Gurney FJ \& Denye V 1972 Immunological responses in pregnancy and survival of fetal homograft. BMJ 3 150-152. (doi:10.1136/bmj.3.5819.150)

Firkin BG, Howard MA \& Radford N 1980 Possible relationship between lupus inhibitor and recurrent abortion in young women. Lancet 316366. (doi:10.1016/S0140-6736(80)90361-X)
Fischer Lindahl K 1997 On naming H2 haplotypes: functional significance of MHC class lb alleles. Immunogenetics 46 53-62. (doi:10.1007/ s002510050242)

Fontenot JD, Gavin MA \& Rudensky AY 2003 Foxp3 programs the development and function of CD4 CD25+ regulatory T cells. Nature Immunology 4 330-336. (doi:10.1038/ni904)

de Fougerolles AR \& Baines MG 1987 Modulation of the natural killer cell activity in pregnant mice alters the spontaneous abortion rate. Journal of Reproductive Immunology 11 147-153. (doi:10.1016/01650378(87)90018-0)

Gendron RL \& Baines MG 1988 Infiltrating decidual natural killer cells are associated with spontaneous abortion in mice. Cellular Immunology $\mathbf{1 1 3}$ 261-267. (doi:10.1016/0008-8749(88)90025-1)

Gendron RL \& Baines MG 1989 Morphometric analysis of the histology of spontaneous fetal resorption in a murine pregnancy. Placenta $\mathbf{1 0}$ 309-318. (doi:10.1016/0143-4004(89)90031-3)

Gendron RL, Farookhi R \& Baines MG 1990 Resorption of CBA/J x DBA/2 mouse conceptuses in $\mathrm{CBA} / \mathrm{J}$ uteri correlates with failure of the fetoplacental unit to suppress natural killer cell activity. Journal of Reproduction and Fertility 89 277-284. (doi:10.1530/jrf.0.0890277)

Gendron RL, Farookhi R \& Baines MG 1992 Murine pregnancies predisposed to spontaneous resorption show alterations in the concentrations of leukotriene B4 and prostaglandin $\mathrm{E}_{2}$. Biology of Reproduction 47 72-75. (doi:10.1095/biolreprod47.1.72)

Girardi G 2011 Role of tissue factor in feto-maternal development: a xiphos. Journal of Thrombosis and Haemostasis 9 250-256. (doi:10.1111/j.15387836.2010.04135.x)

Girardi G, Yarilin D, Thurman JM, Holers VM \& Salmon JE 2006 Complement activation induces dysregulation of angiogenic factors and causes fetal rejection and growth restriction. Journal of Experimental Medicine 203 2165-2175. (doi:10.1084/jem.20061022)

Gordon RD, Simpson E \& Samelson LE 1975 In vitro cell-mediated immune responses to the male specific $(\mathrm{H}-\mathrm{Y})$ antigen in mice. Journal of Experimental Medicine 142 1108-1120. (doi:10.1084/jem.142.5.1108)

Hamilton MS \& Hamilton BL 1987 Environmental influences on immunologically associated spontaneous abortion in $\mathrm{CBA} / \mathrm{J}$ mice. Journal of Reproductive Immunology 11 237-241. (doi:10.1016/01650378(87)90060-X)

Heine O, Neppert J \& Mueller-Eckhardt G 1989 Influence of immunization with allogeneic spleen cells on the number of viable neonates in mice. Journal of Reproductive Immunology 15 169-173. (doi:10.1016/01650378(89)90036-3)

Ho HN, Chen SU, Yang YS, Huang SC, Lee TY \& Gill TJ III 1994 Age, environment, and lymphocyte immunization influence the spontaneous resorption rate in the $\mathrm{CBA} / \mathrm{J} \times \mathrm{DBA} / 2 \mathrm{~J}$ mouse model. American Journal of Reproductive Immunology 31 47-51. (doi:10.1111/j.1600-0897.1994. tb00846.x)

Inada K, Shima T, Nakashima A, Aoki K, Ito M \& Saito S 2013 Characterization of regulatory $\mathrm{T}$ cells in decidua of miscarriage cases with abnormal or normal fetal chromosomal content. Journal of Reproductive Immunology 97 104-111. (doi:10.1016/j.jri.2012.12.001)

Ito $M$, Nakashima $A$, Hidaka T, Okabe $M$, Bac ND, Ina $S$, Yoneda $S$, Shiozaki A, Sumi S, Tsuneyama K et al. 2010 A role for IL-17 in induction of an inflammation at the fetomaternal interface in preterm labour. Journal of Reproductive Immunology 84 75-85. (doi:10.1016/j.jri.2009. 09.005)

Jaiswal MK, Gilman-Sachs A, Chaouat G \& Beaman KD 2011 Placental ATPase expression is a link between multiple causes of spontaneous abortion in mice. Biology of Reproduction 85 626-634. (doi:10.1095/ biolreprod.111.092494)

Janeway CA Jr 1992 The immune system evolved to discriminate infectious nonself from noninfectious self. Immunology Letters 13 11-16.

Janeway CA Jr, Goodnow CC \& Medzhitov R 1996 Immunological tolerance: Danger - pathogen on the premises!. Current Biology 6 519-522. (doi:10.1016/S0960-9822(02)00531-6)

Jensen F, Muzzio D, Soldati R, Fest S \& Zenclussen AC 2013 Regulatory B10 cells restore pregnancy tolerance in a mouse model. Biology of Reproduction 89 1-7. (doi:10.1095.biolreprod.113.110791)

Jiang PJ, Lin QD, Bao SM, Zhao AM, Zhang Y \& Xiao SJ 2009 Relationship between expression of chemokine receptors CCR3, CCR5 and CXCR3 on $\mathrm{CD} 4(+) \mathrm{T}$ cells and spontaneous abortion in mice. Chinese Medical Journal 122 390-395. 
Jin LP, Li DJ, Zhang JP, Wang MY, Zhu XY, Zhu Y, Meng Y \& Yuan MM 2004 Adoptive transfer of paternal antigen-hyporesponsive $T$ cells induces maternal tolerance to the allogeneic fetus in abortion-prone matings. Journal of Immunology 173 3612-3619.

Jin LP, Zhou YH, Wang MY, Zhu XY \& Li DJ 2005 Blockade of CD80 and CD86 at the time of implantation inhibits maternal rejection to the allogeneic fetus in abortion-prone matings. Journal of Reproductive Immunology 65 133-146. (doi:10.1016/j.jri.2004.08.009)

Jin LP, Zhou YH, Zhu XY, Wang MY \& Li DJ 2006 Adoptive transfer of paternal antigen-hyporesponsive $\mathrm{T}$ cells facilitates a Th2 bias in peripheral lymphocytes and at materno-fetal interface in murine abortion-prone matings. American Journal of Reproductive Immunology 56 258-266. (doi:10.1111/j.1600-0897.2006.00425.x)

Kappler JW, Staerz U, White J \& Marrack PC 1988 Self-tolerance eliminates T cells specific for Mls-modified products of the major histocompatibility complex. Nature 332 35-40. (doi:10.1038/332035a0)

Kiger N, Chaouat G, Kolb JP, Wegmann TG \& Guenet JL 1985 Immunogenetic studies of spontaneous abortion in mice. Preimmunization of females with allogeneic cells. Journal of Immunology 134 2966-2970.

Kim HJ, Hsu LYF, Paciuc S, Cristian S, Quintana A \& Hirschhorn K 1975 Cytogenetics of fetal wastage. New England Journal of Medicine 293 844-847. (doi:10.1056/NEJM197510232931703)

Koopman LA, Kopcow HD, Rybalov B, Boyson JE, Orange JS, Schatz F, Masch R, Lockwood CJ, Schachter AD, Park PJ et al. 2003 Human decidual natural killer cells are a unique NK cell subset with immunomodulatory potential. Journal of Experimental Medicine 198 1201-1212. (doi:10.1084/jem.20030305)

Krishnan L, Guilbert LJ, Russell AS, Wegmann TG, Mosmann TR \& Belosevic M 1996 Pregnancy impairs resistance of C57BL.6 mice to Leishmania major infection and causes decreased antigen-specific IFN- $\gamma$ responses and increased production of T helper cytokines. Journal of Immunology 156 644-652.

Kwan WH, van der Touw W \& Heeger PS 2012 Complement regulation of T cell immunity. Immunologic Research 54 247-253. (doi:10.1007/ s12026-012-8327-1)

Laitinen T, Lokki ML, Tulppala M, Ylikorkala O \& Koskimies S 1991 Increased frequency of complement C4 'null' alleles in recurrent spontaneous abortions. Human Reproduction 6 1384-1387.

Lane PJ, Gaspal FM, McConnell FM, Withers DR \& Anderson G 2012 Lymphoid tissue inducer cells: pivotal cells in the evolution of CD4 immunity and tolerance? Frontiers in Immunology 3 24. (doi:10.3389/ fimmu.2012.00024)

Li W, Li B, Fan W, Geng L, Li X, Li L, Huang Z \& Li S 2009 CTLA4lg gene transfer alleviates abortion in mice by expanding CD4+CD25+ regulatory T cells and inducing indoleamine 2,3-dioxygenase. Journal of Reproductive Immunology $\mathbf{8 0}$ 1-11. (doi:10.1016/j.jri.2008.11.006)

Li X, Wang B, Li Y, Wang L, Zhao X, Zhou X, Guo Y, Jiang G \& Yao C 2013 The Th1/Th2/Th17/Treg paradigm induced by stachydrine hydrochloride reduces uterine bleeding in RU486-induced abortion mice. Journal of Ethnopharmacology 145 241-253. (doi:10.1016/j.jep.2012.10.059)

Lin H, Mosmann TR, Guilbert L, Tuntipopipat S \& Wegmann TG 1993 Synthesis of T-helper 2-type cytokines at the maternal-fetal interface. Journal of Immunology 151 4562-4573.

Maloy KJ, Salaun L, Cahill R, Dougan G, Saunders NJ \& Powrie F 2003 CD4+CD25 + TR cells suppress innate immune pathology through cytokine-dependent mechanisms. Journal of Experimental Medicine 197 111-119. (doi:10.1084/jem.20021345)

Mas AE, Petitbarat M, Dubanchet S, Fay S, Ledee N \& Chaouat G 2008 Immune regulation at the interface during early steps of murine implantation: involvement of two new cytokines of the IL-12 family (IL-23 and IL-27) and of TWEAK. American Journal of Reproductive Immunology 59 323-338. (doi:10.1111/j.1600-0897.2007.00567.x)

Matzinger P 1994 Tolerance, danger, and the extended family. Annual Review of Immunology 12 991-1045. (doi:10.1146/annurev.iy.12. 040194.005015)

Matzinger P \& Kamala T 2011 Tissue-based class control: the other side of tolerance. Nature Reviews. Immunology 11 221-230. (doi:10.1038/ nri2940)

McIntyre JA \& Faulk WP 1979 Trophoblast modulation of maternal allogeneic recognition. PNAS 76 4029-4032. (doi:10.1073/pnas.76.8. 4029)
McIntyre JA \& Faulk WP 1983 Recurrent spontaneous abortion in human pregnancy: results of immunogenetical, cellular, and humoral studies. American Journal of Reproductive Immunology 4 165-170. (doi:10. 1111/j.1600-0897.1983.tb00272.x)

McIntyre JA, Faulk WP, Verhulst SJ \& Colliver JA 1983 Human trophoblastlymphocyte cross-reactive (TLX) antigens define a new alloantigen system. Science 222 1135-1137. (doi:10.1126/science.6648525)

McIntyre JA, Coulam CB \& Faulk WP 1989 Recurrent spontaneous abortion. American Journal of Reproductive Immunology 21 100-104. (doi:10.1111/j.1600-0897.1989.tb01011.x)

Medawar PB 1954 Some immunological and endocrinological problems raised by the evolution of viviparity in vetebrates. Symposia of the Society for Experimental Biology 7 320-328.

Mellor AL \& Munn DH 2001 Tryptophan catabolism prevents maternal $\mathrm{T}$ cells from activating lethal anti-fetal immune responses. Journal of Reproductive Immunology 52 5-13. (doi:10.1016/S01650378(01)00118-8)

Mohlin FC, Mercier E, Fremeaux-Bacchi V, Liszewski MK, Atkinson JP, Gris JC \& Blom AM 2013 Analysis of genes coding for CD46, CD55, and C4b-binding protein in patients with idiopathic, recurrent, spontaneous pregnancy loss. European Journal of Immunology 43 1617-1629. (doi:10.1002/eji.201243196)

Moldenhauer LM, Hayball JD \& Robertson SA 2010 Utilising T cell receptor transgenic mice to define mechanisms of maternal $\mathrm{T}$ cell tolerance in pregnancy. Journal of Reproductive Immunology 87 1-13. (doi:10.1016/j.jri.2010.05.007)

Monk JM, Leonard S, McBey BA \& Croy BA 2005 Induction of murine spiral artery modification by recombinant human interferon- $\gamma$. Placenta $\mathbf{2 6}$ 835-838. (doi:10.1016/j.placenta.2004.10.016)

Munn DH, Zhou M, Attwood JT, Bondarev I, Conway SJ, Marshall B, Brown C \& Mellor AL 1998 Prevention of allogeneic fetal rejection by tryptophan catabolism. Science 281 1191-1193. (doi:10.1126/science. 281.5380.1191)

Muzikova E \& Clark DA 1995 Is spontaneous resorption in the DBA/2mated CBA/J mouse due to a defect in "seed" or in "soil"? American Journal of Reproductive Immunology 33 81-85. (doi:10.1111/j.16000897.1995.tb01142.x)

Nakashima A, Shima T, Inada K, Ito M \& Saito S 2012 The balance of the immune system between T cells and NK cells in miscarriage. American Journal of Reproductive Immunology 67 304-310. (doi:10.1111/j.16000897.2012.01115.x)

Nielsen HS, Steffensen R, Varming K, Van Halteren AG, Spierings E, Ryder LP, Goulmy E \& Christiansen OB 2009 Association of HY-restricting HLA class II alleles with pregnancy outcome in patients with recurrent miscarriage subsequent to a firstborn boy. Human Molecular Genetics 18 1684-1691. (doi:10.1093/hmg/ddp077)

Norton MT, Fortner KA, Oppenheimer KH \& Bonney EA 2010 Evidence that CD8 T-cell homeostasis and function remain intact during murine pregnancy. Immunology 131 426-437. (doi:10.1111/j.1365-2567.2010. 03316.x)

Nyirenda MH, Sanvito L, Darlington PJ, O'Brien K, Zhang GX, Constantinescu CS, Bar-Or A \& Gran B 2011 TLR2 stimulation drives human naive and effector regulatory T cells into a Th17-like phenotype with reduced suppressive function. Journal of Immunology $\mathbf{1 8 7}$ 2278-2290. (doi:10.4049/jimmunol.1003715)

Ober C, Karrison T, Odem RR, Barnes RB, Branch DW, Stephenson MD, Baron B, Walker MA, Scott JR \& Schreiber JR 1999 Mononuclear-cell immunisation in prevention of recurrent miscarriages: a randomised trial. Lancet 354 365-369. (doi:10.1016/S0140-6736(98)12055-X)

Oku K, Atsumi T, Bohgaki M, Amengual O, Kataoka H, Horita T, Yasuda S \& Koike T 2009 Complement activation in patients with primary antiphospholipid syndrome. Annals of the Rheumatic Diseases 68 1030-1035. (doi:10.1136/ard.2008.090670)

Porter TF, LaCoursiere Y \& Scott JR 2006 Immunotherapy for recurrent miscarriage. Cochrane Database of Systematic Reviews 19 CD000112.

Prados MB, Solano ME, Friebe A, Blois S, Arck P \& Miranda S 2011 Stress increases VCAM- 1 expression at the fetomaternal interface in an abortion-prone mouse model. Journal of Reproductive Immunology $\mathbf{8 9}$ 207-211. (doi:10.1016/j.jri.2011.01.021)

Redecha P, van Rooijen N, Torry D \& Girardi G 2009 Pravastatin prevents miscarriages in mice: role of tissue factor in placental and fetal injury. Blood 113 4101-4109. (doi:10.1182/blood-2008-12-194258) 
Regan L, Braude PR \& Trembath PL 1989 Influence of past reproductive performance on risk of spontaneous abortion. BMJ 299 541-545. (doi:10.1136/bmj.299.6698.541)

Riella LV, Dada S, Chabtini L, Smith B, Huang L, Dakle P, Mfarrej B, D'Addio F, Adams LT, Kochupurakkal N et al. 2013 B7h (ICOS-L) maintains tolerance at the fetomaternal interface. American Journal of Pathology 182 2204-2213. (doi:10.1016/j.ajpath.2013.02.014)

del Rio R, Sun Y, Alard P, Tung KS \& Teuscher C 2011 H2 control of natural $\mathrm{T}$ regulatory cell frequency in the lymph node correlates with susceptibility to day 3 thymectomy-induced autoimmune disease. Journal of Immunology 186 382-389. (doi:10.4049/jimmunol.1002110)

Rowe JH, Ertelt JM, Xin L \& Way SS 2012a Listeria monocytogenes cytoplasmic entry induces fetal wastage by disrupting maternal Foxp3 + regulatory T cell-sustained fetal tolerance. PLoS Pathogens 8 e1002873. (doi:10.1371/journal.ppat.1002873)

Rowe JH, Ertelt JM, Xin L \& Way SS 2012b Pregnancy imprints regulatory memory that sustains anergy to fetal antigen. Nature 490 102-106. (doi:10.1038/nature11462)

Sakaguchi S, Yamaguchi T, Nomura T \& Ono M 2008 Regulatory T cells and immune tolerance. Cell 133 775-787. (doi:10.1016/j.cell.2008.05.009)

Sakaguchi S, Vignali DA, Rudensky AY, Niec RE \& Waldmann H 2013 The plasticity and stability of regulatory T cells. Nature Reviews. Immunology 13 461-467. (doi:10.1038/nri3464)

Sasaki Y, Sakai M, Miyazaki S, Higuma S, Shiozaki A \& Saito S 2004 Decidual and peripheral blood CD4 + CD25 + regulatory T cells in early pregnancy subjects and spontaneous abortion cases. Molecular Human Reproduction 10 347-353. (doi:10.1093/molehr/gah044)

Scott DM, Ehrmann JE, Ellis PS, Bishop CE, Agulnik AI, Simpson E \& Mitchell MJ 1997 Identification of a mouse male-specific transplantation antigen H-Y. Nature 376 695-698. (doi:10.1038/376695a0)

Seong SY \& Matzinger P 2004 Hydrophobicity: an ancient damageassociated molecular pattern that initiates innate immune responses. Nature Reviews. Immunology 4 469-478. (doi:10.1038/nri1372)

Shearman RP \& Garrett WJ 1963 Double-blind study of effect of 17-hydroxyprogesterone caproate on abortion rate. BMJ 1 292-295. (doi:10.1136/bmj.1.5326.292)

Simpson E, Scott D \& Chandler P 1997 The male-specific histocompatibility antigen, H-Y: a history of transplantation, immune response genes, sex determination, and expression cloning. Annual Review of Immunology 15 39-61. (doi:10.1146/annurev.immunol.15.1.39)

Singh J, Ahmed A \& Girardi G 2011 Role of complement component C1q in the onset of preeclampsia in mice. Hypertension 58 716-724. (doi:10.1161/HYPERTENSIONAHA.111.175919)

Spits H \& Cupedo T 2012 Innate lymphoid cells: emerging insights in development, lineage relationships, and function. Annual Review of Immunology 30 647-675. (doi:10.1146/annurev-immunol-020711075053)

Tafuri A, Alferink J, Moller P, Hammerling GJ \& Arnold B 1995 T cell awareness of paternal alloantigens during pregnancy. Science $\mathbf{2 7 0}$ 630-633. (doi:10.1126/science.270.5236.630)

Tang AW, Alfirevic Z \& Quenby S 2011 Natural killer cells and pregnancy outcomes in women with recurrent miscarriage and infertility: a systematic review. Human Reproduction 26 1971-1980. (doi:10. 1093/humrep/der164)

Tang AW, Alfirevic Z, Turner MA, Drury JA, Small R \& Quenby S 2013 A feasibility trial of screening women with idiopathic recurrent miscarriage for high uterine natural killer cell density and randomizing to prednisolone or placebo when pregnant. Human Reproduction 28 1743-1752. (doi:10.1093/humrep/det117)

Taylor C \& Faulk WP 1981 Prevention of recurrent abortion with leucocyte transfusions. Lancet 2 68-70. (doi:10.1016/S0140-6736(81)90413-X)

Teles A, Thuere C, Wafula PO, El-Mousleh T, Zenclussen ML \& Zenclussen AC 2013 Origin of Foxp3(+) cells during pregnancy. American Journal of Clinical and Experimental Immunology 2 222-233.

Thangavelu G, Gill RG, Boon L, Ellestad KK \& Anderson CC 2013 Control of in vivo collateral damage generated by $\mathrm{T}$ cell immunity. Journal of Immunology 191 1686-1691. (doi:10.4049/jimmunol.1203240)

Thornton AM \& Shevach EM 1998 CD4+CD25+ Immunoregulatory $\mathrm{T}$ cells suppress polyclonal $\mathrm{T}$ cell activation in vitro by inhibiting interleukin 2 production. Journal of Experimental Medicine 188 287-296. (doi:10.1084/jem.188.2.287)
Tung KS \& Teuscher C 1995 Mechanisms of autoimmune disease in the testis and ovary. Human Reproduction Update 1 35-50. (doi:10.1093/ humupd/1.1.35)

Vance RE, Jamieson AM, Cado D \& Raulet DH 2002 Implications of CD94 deficiency and monoallelic NKG2A expression for natural killer cell development and repertoire formation. PNAS 99 868-873. (doi:10.1073/ pnas.022500599)

Wafula PO, Teles A, Schumacher A, Pohl K, Yagita H, Volk HD \& Zenclussen AC 2009 PD-1 but not CTLA-4 blockage abrogates the protective effect of regulatory $\mathrm{T}$ cells in a pregnancy murine model. American Journal of Reproductive Immunology 62 283-292. (doi:10.1111/j.1600-0897.2009.00737.x)

Weil RJ \& Tupper C 1960 Personality, life situation, and communication: a study of habitual abortion. Psychosomatic Medicine 22 448-455.

Yin Y, Han X, Shi Q, Zhao Y \& He Y 2012 Adoptive transfer of CD4+ $\mathrm{CD} 25+$ regulatory $\mathrm{T}$ cells for prevention and treatment of spontaneous abortion. European Journal of Obstetrics, Gynecology, and Reproductive Biology 161 177-181. (doi:10.1016/j.ejogrb.2011.12.023)

Yin T, Huang F, Ren J, Liu W, Chen X, Li L, Xie D \& Lu Y 2013 Bilateral sudden hearing loss following habitual abortion: a case report and review of literature. International Journal of Clinical and Experimental Medicine 6 720-723.

Zelinskyy G, Werner T \& Dittmer U 2013 Natural regulatory T cells inhibit production of cytotoxic molecules in CD8 + T cells during low-level Friend retrovirus infection. Retrovirology 10 109. (doi:10.1186/17424690-10-109)

Zenclussen AC, Blois S, Stumpo R, Olmos S, Arias K, Malan Borel I, Roux ME \& Margni RA 2003 Murine abortion is associated with enhanced interleukin-6 levels at the feto-maternal interface. Cytokine 24 150-160. (doi:10.1016/j.cyto.2003.08.002)

Zenclussen AC, Gerlof K, Zenclussen ML, Sollwedel A, Bertoja AZ, Ritter T, Kotsch K, Leber J \& Volk HD 2005 Abnormal T-cell reactivity against paternal antigens in spontaneous abortion: adoptive transfer of pregnancyinduced $\mathrm{CD} 4+\mathrm{CD} 25+\mathrm{T}$ regulatory cells prevents fetal rejection in a murine abortion model. American Journal of Pathology 166 811-822. (doi:10.1016/S0002-9440(10)62302-4)

Zenclussen ML, Anegon I, Bertoja AZ, Chauveau C, Vogt K, Gerlof K, Sollwedel A, Volk HD, Ritter T \& Zenclussen AC 2006 Over-expression of heme oxygenase- 1 by adenoviral gene transfer improves pregnancy outcome in a murine model of abortion. Journal of Reproductive Immunology 69 35-52. (doi:10.1016/j.jri.2005.10.001)

Zhang M \& Carroll MC 2007 Natural antibody mediated innate autoimmune response. Molecular Immunology 44 103-110. (doi:10.1016/j.molimm. 2006.06.022)

Zhang H, Hu X, Liu X, Zhang R, Fu Q \& Xu X 2012 The Treg/Th17 imbalance in Toxoplasma gondii-infected pregnant mice. American Journal of Reproductive Immunology 67 112-121. (doi:10.1111/j.1600-0897. 2011.01065.x)

Zhao FX, Zhang YY, Liu RH \& Li SM 2007 Effect of blockage of costimulatory signal on murine abortion-prone model. Chinese Medical Journal 120 1247-1250.

Zhou WH, Dong L, Du MR, Zhu XY \& Li DJ 2008 Cyclosporin A improves murine pregnancy outcome in abortion-prone matings: involvement of CD80/86 and CD28/CTLA-4. Reproduction 135 385-395. (doi:10.1530/ REP-07-0063)

Zhu XY, Zhou YH, Wang MY, Jin LP, Yuan MM \& Li DJ 2005 Blockade of CD86 signaling facilitates a Th2 bias at the maternal-fetal interface and expands peripheral CD4 + CD25 + regulatory T cells to rescue abortionprone fetuses. Biology of Reproduction 72 338-345. (doi:10.1095/ biolreprod.104.034108)

Zinkernagel RM \& Hengartner H 2004 On immunity against infections and vaccines: credo. Scandinavian Journal of Immunology 60 9-13. (doi:10.1111/j.0300-9475.2004.01460.x)

Received 13 November 2013

First decision 19 December 2013

Revised manuscript received 22 January 2014

Accepted 27 January 2014 